\title{
JURISDIKCE MEZINÁRODNÍHO SOUDNÍHO DVORA VE SPORNÝCH VĚCECH: STOLETÝ P̌̌ÍBĚH VLAJKOVÉ LODI MEZINÁRODNÍ SPRAVEDLNOSTI
}

\author{
SOŇA ŠINDELKOVÁ*
}

\begin{abstract}
Jurisdiction of the International Court of Justice in Contentious Cases: A Hundred Years Old Story of the Flagship of International Justice

This paper deals with jurisdiction of the International Court of Justice (ICJ) in contentious cases. It looks into functioning of the jurisdiction based on the consent of litigant States, including the limits and impacts of the principle of consent. Jurisdiction of the ICJ is a legal notion of crucial importance. Its character is determined by the horizontal arrangement of international law. Some basic knowledge of the background of the mechanism of contentious jurisdiction is needed for comprehension. The historical background and development is of particular relevance here. The legal source of most of jurisprudence of the ICJ concerning its contentious jurisdiction is Article 36 paragraph 6 of the ICJ Statute. It provides for the compétence de la compétence principle. Indeed, it is the interplay of the principle of consent and the principle of compétence de la compétence that is the crucial point of the mechanism. Jurisdiction ratione personae is delimited by the monopoly of States regarding the access to the contentious procedure. A simple basic rule and yet the case-law on the access to the ICJ is affected by certain inconsistency. The jurisdiction ratione materiae is based on consent of parties of the dispute concerned. There are several ways of accepting the ICJ jurisdiction. De lege lata, the place of the ICJ within the system of methods of peaceful settlement of international disputes is equal to the other methods.
\end{abstract}

Keywords: international justice; International Court of Justice; jurisdiction in contentious cases; the principle of consensual jurisdiction; the compétence de la compétence principle

Klíčová slova: mezinárodní soudnictví; Mezinárodní soudní dvůr; jurisdikce ve sporných věcech; princip konsensuální jurisdikce; princip compétence de la compétence

DOI: $10.14712 / 23366478.2019 .41$

\section{1. ÚVOD}

Za dva, resp. tři roky (podle toho, zda zvolíme za rozhodné datum schválení Statutu, anebo inaugurační zasedání) budeme oslavovat sté výročí vzniku Stálého dvora mezinárodní spravedlnosti (dále též jen ,SDMS“), předchůdce Mezinárodního

\footnotetext{
* Autorka působí v Kanceláři vládního zmocněnce pro zastupování České republiky před Soudním dvorem EU, která je součástí Ministerstva zahraničních věcí ČR. Veškeré názory vyjádřené v tomto článku jsou výhradně její vlastní.
} 
soudního dvora (dále též jen „Dvůr“ nebo „MSD“). Nadcházející sté narozeniny Světového soudu, jak též bývá (poněkud eufemisticky) MSD, potažmo SDMS, nazýván, vybízejí k zamyšlení nad jeho úlohou a nad cestou, kterou za posledních sto let mezinárodní spravedlnost urazila.

Procesní rovina fungování MSD zůstává ve stínu jeho hmotněprávní judikatury. Aby však bylo možné realisticky zhodnotit působení Dvora, jeho možnosti a perspektivu, nestačí studovat pouze hmotně právní kasuistiku, ale je třeba se podrobně zabývat i samotným Dvorem a řízením, které před ním probíhá. Mimořádný význam má pak vymezení jeho pravomoci i způsob, jakým je v praxi tato pravomoc uplatňována.

Právě (a pouze) vymezením pravomoci Dvora ve sporných věcech se tento článek zabývá. (Jakkoli jsou posudky MSD nástrojem zásadního významu, rozhodování sporů je tím, co činí soud soudem.) Problematika sporné jurisdikce se při hlubším zkoumání ukazuje jako natolik významný a zároveň složitý právní jev, že si pozornost jako svébytné téma rozhodně zasluhuje.

MSD je v mnoha směrech jakousi vlajkovou lodí mezinárodního soudnictví. Jeho jurisdikce ve sporných věcech představuje vysoce relevantní pohled na mezinárodní spravedlnost. Nad svrchovanými státy ex lege nestojí a nemůže stát žádná jiná moc vyšší, tedy ani moc soudní, pokud ji státy neakceptují z vlastní vưle. To je koncept tak odlišný oproti principům vnitrostátního práva, že si zasluhuje pozornost již proto, abychom si byli neustále vědomi úlohy a limitů mezinárodního soudnictví, resp. v tomto př́padě MSD, jakož i místa, které soudnictví zaujímá v katalogu prostř̌edků řešení mezistátních sporů.

V souvislosti s jurisdikcí Dvora se tak nabízí se řada otázek. Jak se právo, praxe států a především samotná rozhodovací činnost Dvora vyrovnává se specifiky horizontálního systému mezinárodního práva? Kdy a koho může Dvůr soudit? A konkrétněji, jak Dvůr rozhoduje o vlastní jurisdikci a čím je v tomto ohledu determinován? Jak vymezení jeho pravomoci vzniklo a jakou prošlo za sto let proměnou?

Pokusím se představit spornou jurisdikci MSD jako mezinárodně právní fenomén zásadního významu, jako fenomén komplexní a komplikovaný a také tak trochu - s akcentem na historický vývoj - jako př́běh, který se s pozoruhodnou kontinuitou píše již necelých sto let. I z tohoto důvodu je zde kladen důraz na starší judikaturu, včetně judikatury SDMS, nebot' se tak zřetelně ukazují kořeny, na nichž aktuální rozhodovací praxe spočívá. To je obzvláště relevantní i proto, že pravidla týkající se jurisdikce jsou v psaném právu velice stručná, prričemž reálná, aplikovaná pravidla, jež se při rozhodování o jurisdikci uplatňují, jsou bez určité znalosti judikatury prakticky neuchopitelná. Zdůrazněny jsou zde zejména ty rozsudky, kde Dvůr vymezil směr své další cesty a které jsou pro další vývoj klíčové.

Tento článek neaspiruje na poskytnutí popisu všech aspektů problematiky, tím méně pak na komplexní zpracování veškeré judikatury Dvora ve věcech vlastní jurisdikce. Pro prezentaci tématu jsem zvolila stručný průřez základními aspekty sporné jurisdikce a popis rámce, $v$ němž se pravomoc Dvora uplatňuje, s akcentem na stěžejní principy formulované judikaturou. Vlastně jde o výše naznačený návrat ke kořenům.

S tím je spojen důraz na primární prameny. Navíc, ačkoli MSD a jeho působení přirozeně přitahuje rozsáhlou pozornost doktríny, podrobnější analýza otázek jeho pravomoci, která by přesáhla obecnou rovinu (několik obvyklých stran v monografiích), se 
v sekundárních pramenech hledá velmi těžko. Přitom se jedná o klíčový prvek fungování nejenom Dvora, ale do jisté míry i samotného mezinárodního práva.

\title{
2. PODSTATA JURISDIKCE MSD VE SPORNÝCH VĚCECH
}

\subsection{POVAHA A SPECIFIKA SPORNÉ JURISDIKCE MSD V PROSTŘEDÍ HORIZONTÁLNÍHO SYSTÉMU MEZINÁRODNÍHO PRÁVA}

\begin{abstract}
„,Tvář́ v tvář velkému množství konfliktů v dnešním světě, které nespadají do pravomoci Mezinárodního soudního dvora, je obecná veřejnost často postavena před otázku, co je vlastné úlohou mezinárodního soudu. " (Mohammed Bedjaoui, predseda Mezinárodního soudního dvora v projevu k Valnému shromážděni OSN dne 12. ř̉jna 1995)
\end{abstract}

Mezinárodní právo upravuje především vztahy mezi svrchovanými státy a Světový soud ${ }^{1}$ působí v prostředí, kde platí, že par in parem non habet imperium.

Nejen obecná, ale i odborná veřejnost se čas od času ocitá před otázkou, nakolik je mezinárodní právo efektivním regulátorem mezinárodních vztahů, pokud nedisponuje skutečnou obligatorní soudní mocí. Za těchto okolností je sám systém mezinárodního práva vystavován konfrontaci s lidskou touhou po institucionální spravedlnosti, formální rovnosti a uplatňování řádu.

Když Jiří z Poděbrad v rámci svého projektu mezinárodní mírové organizace v šedesátých letech patnáctého století navrhoval, aby „,v připadě, že vzniknou nějaké pře a různice mezi králi a knižaty a jinými účastníky naši smlouvy, byl jeden druhému povinen a vázán pred soudem naším podle práva odpovidati a sím spor vésti a zachovávati přitom ustanovení, rozhodnutí a nařizení, jež naši mluvči a zástupci nebo jejich většina v shromáždění samém vydaji a ustanovi" ${ }^{2}$ značně předběhl nejen svou, ale i naši dobu. Ani pět a půl století později nejsou státy navzájem povinny a vázány před soudem odpovídati, a to ani státy, které jsou stranami Statutu MSD. Tím se otevírá prostor k úvahám o realitě mezinárodního soudnictví a jeho perspektivě.

Jak se tedy současná mezinárodní spravedlnost, potažmo fungování MSD vyrovnává s tím, že suverénní moc nelze zásadně podrobit žádné jiné moci vyšší, tedy ani mezinárodní moci soudní? Pomineme-li lakonickou odpověd', že dosti komplikovaně, v právní rovině lze obecně uvést, že k tomu, aby nad suverénními subjekty mezinárodního práva mohla být vykonávána jakákoli soudní pravomoc, je nutný jejich souhlas. Tento princip je označován jako zásada konsensuální jurisdikce: stát může být podroben mezinárodní soudní moci jedině tehdy, pokud sám projevem vlastní svrchované moci tuto mezinárodní soudní moc přijme.

Dvưr tuto zásadu potvrdil v rozsudku Monetary Gold Removed from Rome (1954), kde konstatoval, že může vykonat svou jurisdikci pouze nad státem, který k tomu udělil

1 Toto označení je typické spíše pro anglofonní literaturu a v českém prostředí působí nezvykle, nicméně zde výstižně zastřešuje SDMS a MSD zároveň.

2 Citováno podle: VESELÝ, Z. Dějiny českého státu v dokumentech. Victoria Publishing, 1995. 
souhlas. Přitom tuto zásadu označil za ustálený princip mezinárodního práva, jenž byl začleněn do Statutu, ${ }^{3}$ a ve své judikatuře ji důsledně potvrzuje. ${ }^{4}$ Ještě dříve a obecněji (ve vztahu ke všem formám mírového urovnávání sporů) tento princip potvrdil v roce 1927 SDMS v odpovědi na žádost o posudek ve věci Status of Eastern Carelia. ${ }^{5}$

Mechanismus založení jurisdikce MSD se zakládá na následujících principech.

Stranami sporného rrízení mohou být výhradně státy. K tomu, aby stát mohl být spornou stranou v konkrétním řízení, musí být splněny dvě podmínky: zaprvé, stát musí mít ke Dvoru př́stup a, zadruhé, musí projevem své svrchované moci přijmout jurisdikci Dvora. Přitom ne všechny státy, které mají ke Dvoru př́stup, přijaly jeho jurisdikci. Jurisdikce Dvora není obligatorní ani pro strany jeho Statutu.

Státy přijímají př́slušnost Dvora výhradně z vlastní vůle. K tomu, aby Dvůr mohl projednat určitý spor, musí obě strany, tedy i strana žalovaná, dát souhlas s jeho jurisdikcí. Lze tak učinit několikerým způsobem (prohlášením podle čl. 36 odst. 2 Statutu MSD, doložkou v mezinárodní smlouvě, uzavřením zvláštní dohody, př́padně způsobem nazývaným forum prorogatum).

Na základě tohoto rámce vytvořila rozhodovací praxe Dvora (MSD i jeho předchůdce) soubor poměrně složitých pravidel, na nichž záleží, zda bude Dvưr oprávněn projednat konkrétní spor. Tato pravidla jsou sice primárně procesního charakteru, ale svým významem procesní rovinu dalece přesahují.

\subsection{VÝZNAM JURISDIKCE MSD VE SPORNÝCH VĚCECH}

„Často se upozorñovalo na to, že téměr ve všech př́padech byly rozsudky Mezinárodního soudního dvora a jeho předchůdce, Stálého dvora mezinárodni spravedlnosti, řádně přijaty všemi stranami, jakoby se tím vyrovnávala skutečnost, že na rozdíl od státniho práva nemǐze být před tyto mezinárodni soudy predveden žádný stát bez vlastního předběžného souhlasu. " (H. L. Hart, Pojem práva)

Význam problematiky sporné jurisdikce se uplatňuje v různých rovinách. Nejzřetelnější je rovina procesní, o čemž svědčí bohatá judikatura reflektující právní „bitvy“ o jurisdikci v jednotlivých řízeních. Ty přirozeně nastávají v zásadě v situacích, kdy je ř́zení zahajováno žalobou a žalovaná strana se jurisdikci Dvora brání.

3 Case of the monetary gold removed from Rome in 1943 (Preliminary Question), Judgment of June 15th,1954: I.C.J. Reports 1954, p. 19

4 Např. Continental Shelf (Libyan Arab Jamahiriya/Malta), Application for Permission to Intervene, Judgment, ICJ Reports 1984, p. 25 (viz odst. 40); Military and Paramilitary Activities in and against Nicaragua (Nicaragua v. United States of America), Jurisdiction and Admissibility, Judgment, ICJ Reports 1984, p. 431 (viz odst. 88); Frontier Dispute (Burkina Faso/Republic of Mali), Judgment, ICJ. Reports 1986, p. 579 (viz odst. 49); Land, Island and Maritime Frontier Dispute (El Salvador/Honduras), Application to Intervene, Judgment, I. C. J. Reports1990, pp. 114-116 (viz odst. 54-56), p. 112 (viz odst. 73); Certain Phosphate Lands in Nauru (Nauru v. Australia), Preliminary Objections, Judgment, ICJ. Reports 1992, pp. 259-262 (viz odst. 50-55), East Timor (Portugal v. Australia), Judgment, ICJ Reports 1995, p. 90 (viz odst. 26).

5 „It is well established in international law that no State can, without its consent, be compelled to submit its disputes with other States either to mediation or to arbitration, or to any other kind of pacific settlement." (Status of Eastern Carelia, Reply to request of advisory opinion, 1923 PCIJ Series B, No. 5, p. 27) 
Význam jurisdikce však procesní rovinu výrazně přesahuje, nebot' vymezuje potenciál Dvora, jeho reálnou možnost judikovat. Zároveň lze rozsah, ve kterém je jurisdikce Dvora státy přijímána, chápat jako určitý indikátor autority a důvěry, které se ze strany států Dvưr těší.

Jurisdikce Dvora představuje základ, na němž vyrůstá stavba hmotněprávní kasuistiky. Rozsudky Dvora jsou mimořádně významným prostředkem nalézání práva a jeho rozvoje. Mnoho států však neuznává v žádné formě jeho jurisdikci, většina pak neučinila prohlášení o přijetí tzv. obligatorní jurisdikce ve smyslu čl. 36 odst. 2 Statutu MSD. Státy, které takové prohlášení učinily, přijetí jurisdikce obvykle omezují výhradami. A je-li v praxi podána žaloba, která se coby právního základu jurisdikce dovolává prohlášení nebo jurisdikční doložky mezinárodní smlouvy, žalovaná strana obvykle podává proti soudní př́slušnosti námitky. Následuje řízení o tom, zda Dvưr je, či není př́slušný. Všechny tyto překážky musí být - z hlediska jurisdikce - v zásadě překonány, aby Dvưr mohl meritorně rozhodnout konkrétní spor.

Znalost pravidel, jimiž se problematika jurisdikce řídí, jakož i znalost fungování těchto pravidel v praxi je klíčem k pochopení role, kterou Dvưr sehrává v mezinárodních vztazích. A zejména je podmínkou $\mathrm{k}$ tomu, aby očekávání $\mathrm{v}$ tento soud kladená byla jeho skutečné úloze adekvátní.

Princip konsensuální jurisdikce lze vnímat též jako určitou „vlastnost“ současného mezinárodního práva a lze na něm demonstrovat řadu jeho rysů (jako je zásada svrchované rovnosti či princip svobodné volby prostředků řešení mezinárodních sporů, je zde např́iklad ale i vazba na mezinárodně právní subjektivitu a další souvislosti).

\subsection{K NĚKTERÝM POJMU゚M}

Procesní právo upravující řízení před MSD je zcela autonomní systém, a to i z hlediska terminologického. Je proto vhodné provést upřesnění některých pojmů. „Ius dicere“ aneb jurisdikce, př́slušnost, kompetence či soudní pravomoc. V užívání těchto výrazů se obtížně hledá systém, a to dokonce i v rámci jediného jazyka. ${ }^{6}$ Nicméně všechny uvedené pojmy jsou víceméně synonyma a označují oprávnění Dvora rozhodovat ve věci samé. ${ }^{7}$

6 V českém znění Statutu MSD, publikovaném pod č. 30/1947 Sb., je Kapitola II, která vymezuje jurisdikci, označená názvem „Přrislušnost Dvora“. České sekundární prameny pak porůznu běžně hovoří o jurisdikci, kompetenci či soudní pravomoci. Anglická terminologie pracuje s pojmy „,competence“ a ,jurisdiction“" Kapitola II Statutu MSD je nazvána „Competence of the Court“. Čl. 36 Statutu MSD však pracuje s pojmem ,jurisdiction“. Zdá se tedy, jako by anglická terminologie inklinovala k pojmu „,competence“ při označování pravomoci Dvora v obecném smyslu, zatímco ,jurisdiction“ obvykle označuje př́ílušnost ve vztahu ke konkrétnímu př́padu, tj. v textu a při aplikaci čl. 36 (tedy i v rozsudcích o jurisdikci: „Jurisdiction of the Court"), ale neplatí to beze zbytku. Pokud jde o texty francouzské, Statut MSD pracuje více s pojmem ,compétence“, ovšem termín ,juridiction“ používá také. Napřr. např́ílad čl. 36 odst. 1 Statutu MSD hovoří o „compétence“, druhý odstavec téhož článku (ve vztahu k prohlášení o přijetí jurisdikce) a dokonce i čl. 37 Statutu používá termín ,juridiction“. Rozsudky o své př́slušnosti pak Dvưr označuje „Compétence de la Cour".

7 Obdobně se k problému terminologické nejednoznačnosti postavil v roce 1924 SDMS ve věci The Mavrommatis Palestine Concessions, kde se odmítl pustit do hry s právními pojmy a uvedl, že: „Dvưr nemusí zjištovat, jaké jsou, v rüzných procesních kodexech a v různých právních terminologiích, specifické charakteristiky takové námitky; zejména nemusí posuzovat, zda ,competence 'a ,jurisdiction', , incompétence ‘ 
Jurisdikce sporná a posudková představují bezproblémovou dvojici. Jurisdikcí ve sporných věcech se rozumí pravomoc rozhodovat spory mezi státy, které mají ke Dvoru př́stup; posudkovou jurisdikcí se rozumí pravomoc podle čl. 96 Charty OSN a Kapitoly IV Statutu MSD. Pro upřesnění lze dodat, že jurisdikce ve sporných věcech se často označuje zkráceně jako „sporná jurisdikce“ (angl. contentious jurisdiction, fr. compétence contentieuse), což může být výraz poněkud zavádějící, nebot' by mohl znamenat pravomoc, o kterou se vede spor (což je ostatně často ten prípad). Zde je přirozeně použiván ve smyslu pravomoci ve sporných věcech.

Jurisdikce materiální a personální. V řízení před MSD jurisdikce ratione personae označuje okruh subjektů, které jsou oprávněny účastnit se sporného rrízení, resp. oprávněny přijímat materiální jurisdikci Dvora. Materiální jurisdikce pak vymezuje, na jaké spory soudní pravomoc dopadá. Ve vztahu k MSD existuje mezi těmito dvěma kategoriemi „třecí plocha“. Existence sporu s určitými znaky je podmínkou materiální jurisdikce, ale podmínka, zda a kdy jde o spor mezinárodní, tedy mezi subjekty mezinárodního práva, přesahuje do personální jurisdikce. ${ }^{8}$

Pojem obligatorni jurisdikce je z hlediska možných nejasností nejproblematičtější. Je používán ve dvojím smyslu.

Zaprvé jím lze rozumět soudní pravomoc, jakou známe z vnitrostátního práva, tedy nezávislou na vůli subjektů práva, v konkrétním sporu na vůli žalovaného. To je skutečná obligatorní soudní pravomoc. Jejím protějškem je fakultativní jurisdikce, jakožto jurisdikce odvozená od vůle subjektů práva (resp. sporných stran), jurisdikce „zvolená“, zakládaná právním úkonem.

V souvislosti s MSD se však hovoří o obligatorní jurisdikci spíše v druhém smyslu, a to o takzvané obligatorní jurisdikci, tj. jurisdikci přijaté prohlášením podle čl. 36 odst. 2 Statutu MSD. Toto prohlášení je také běžně nazýváno jako prohlášení o přijetí obligatorní jurisdikce. ${ }^{9}$ Pod obligatorní jurisdikci někdy bývá zahrnována i jurisdikce přijatá na základě doložek mezinárodních smluv. ${ }^{10}$ To lze označit za obligatorní jurisdikci v širším smyslu. Protějškem takto definované obligatorní jurisdikce (tj. jako jurisdikce založené před vznikem sporu) je dobrovolná jurisdikce (voluntary jurisdiction). Tou se obvykle rozumí jurisdikce založená smluvně, kompromisem, tedy smlouvami ad hoc o založení jurisdikce Dvora pro jednotlivý spor, tzn. ve vztahu k již vzniklému sporu. Do této kategorie spadá i forum prorogatum.

$a$, fin de non-recevoir ' by mély být vždy a ve všech souvislostech považovány za synonyma." (The Mavrommatis Palestine Concessions, Series A. No. 2, August 30th, 1924, p. 10).

8 Příkladem je institut diplomatické ochrany, o níž se obvykle pojednává v souvislosti s personální jurisdikcí, dle mého soudu se jedná spíše o záležitost jurisdikce materiální.

$9 \mathrm{Na}$,zrádnost“ pojmu obligatorní jurisdikce upozorňuje nauka. Např́́klad Stanimir Alexandrov konstatuje: „obligatorni jurisdikce neni skutečně obligatorni" (ALEXANDROV, S. The Compulsory Jurisdiction of the International Court of Justice: How Compulsory Is It? Chinese Journal of International Law, 2006, Vol. 5, No. 1, 29-38).

10 Do obligatorní jurisdikce zahrnují jurisdikci založenou kompromisní doložkou mezinárodní smlouvy např́iklad Mikulka a Tomka. Toto pojetí není v nauce ojedinělé. Kritériem obligatorní jurisdikce je v tomto př́ípadě znak spočívající v tom, že příslušnost Dvora k rozhodnutí určitého sporu je dána již v okamžiku, kdy tento spor vzniká. (MIKULKA, V. - TOMKA, P. Československo a Medzinárodný súdný dvor - tempora mutantur? Právník, 1990, č. 5). 
Konsensuální jurisdikcí lze rozumět jurisdikci závislou na vůli obou stran sporu. Jakkoli můžeme jurisdikci Dvora přijatou prohlášením podle čl. 36 odst. 2 Statutu MSD nazývat obligatorní, nemění to nic na její konsensuální podstatě.

„Konsensuální obligatorní jurisdikce" jako základní atribut i paradox současného systému. Jurisdikce MSD je vždy konsensuální. Přesto se však u jurisdikce založené určitým způsobem setkáváme s prŕívlastkem obligatorní. Dospíváme tak ke „konsensuální obligatorní jurisdikci“, tedy k pojmu obsahujícímu vnitřní rozpor. Jde částečně o dědictví pramenící z původní představy, že opční prohlášení budou prostředkem či jakýmsi mostem $\mathrm{k}$ dosažení skutečné obligatorní soudní pravomoci, nebo alespoň stavu, který by se jí blížil. Na druhou stranu, jurisdikce přijatá předem, tedy na základě jednostranného prohlášení i na základě kompromisních doložek mezinárodních smluv (obligatorní jurisdikce v širším smyslu), nese znaky, které ji ke skutečné obligatorní jurisdikci opravdu posouvají. Jakkoli lze „konsensuální obligatorní jurisdikci“ v pravém smyslu označit ze striktně logického hlediska za pojmový nesmysl, skutečností zůstává, že je jedním z charakteristických prvků systému jurisdikce Dvora a je zdrojem i důsledkem řady jistých logických ústupků, s nimiž se v judikatuře i v teorii setkáváme.

\section{HISTORICKÝ VÝVOJ}

\subsection{VZNIK PRAVIDEL O JURISDIKCI VE STATUTU SDMS}

„Stezka světového pokroku leží v současné době zahalena v mlhách, ale tu a tam se objevuji záblesky světla a ozařují cestu. “

(Sir Eric Drummond, Generální tajemník Společnosti národi̊, v projevu při otevření SDMS)

Pro pochopení úpravy př́slušnosti Dvora a hodnocení její efektivity je důležité vzít v úvahu okolnosti vzniku tohoto systému. ${ }^{11}$

SDMS vzniká v době, kdy určujícím elementem mezinárodního práva je neomezená státní suverenita. Světová válka nicméně vnesla do řešení mezistátních sporů určitou změnu. ${ }^{12}$ Diskuse v rámci př́prav Statutu SDMS pak nastolily otázku, zda je přednost státní suverenity před mezinárodní soudní mocí nevyhnutelná. Odehrál se souboj mezi konceptem skutečné obligatorní jurisdikce a jurisdikce fakultativní.

Rada Společnosti národů, která byla pověřena na základě čl. 14 Paktu Společnosti národů př́ipravou návrhu statutu SDMS, $\mathrm{k}$ tomu v roce 1920 jmenovala Poradní právní výbor. ${ }^{13}$ Ustanovení o soudní pravomoci byla stěžejní otázkou. Personální jurisdikce

11 S ohledem omezený rozsah článku a relativně úzce vymezené téma historickou část omezím na přibližení vzniku mechanismu soudní př́slušnosti v roce 1920 a jeho následné obnovení, resp. znovupotvrzení v roce 1945.

12 Jejím normativním výrazem byly čl. 12 a 13 Paktu Společnosti národů, kde členové deklarovali ochotu využívat k řešení svých sporů rozhodčí nebo soudní ŕízení.

13 Své zástupce ve Výboru měly Japonsko, Španělsko, Brazílie, Belgie, Norsko, Francie, Nizozemsko, Spojené království, Itálie a USA. Jeho předsedou byl Baron Descamps (Belgie). 
větší spory ve Výboru nepřinesla. ${ }^{14}$ Naproti tomu otázka jurisdikce ratione materiae představovala jeden z nejspornějších bodů. Na jedné straně stáli zastánci (skutečné) obligatorní jurisdikce - rozumí se, že pro strany Statutu - přičemž pro některé členy Výboru to byla nutná podmínka, aby nový orgán byl orgánem soudním a nikoli arbitrážním, ${ }^{15}$ na straně druhé zastánci jurisdikce fakultativní.

V Poradním právním výboru koncept obligatorní jurisdikce pro signatářské státy zvítězil. (Mezinárodní společenství vlastně nikdy nebylo skutečné obligatorní jurisdikci blíže, než právě v době, kdy byl připravován návrh př́íslušných ustanovení Statutu SDMS.) Rada Společnosti národů však tento koncept odmítla, s př́znivým přijetím se nesetkal ani ve Shromáždění. ${ }^{16} \mathrm{Z}$ diskusí v orgánech Společnosti národů nakonec vzešlo ustanovení, které v podstatě odpovídá dnešnímu čl. 36 Statutu MSD. V září roku 1921 vstoupil Statut SDMS v platnost.

Statut SDMS byl ve vztahu k Paktu Společnosti národů samostatnou smlouvou. Prohlášení o přijetí jurisdikce se činila přijetím opční doložky, která byla připojena k Podpisovému protokolu. Jako dědictví tohoto uspořádání se dodnes ve vztahu k prohlášením o přijetí obligatorní jurisdikce použivá zažitý pojem „optional clause system“, přestože v př́ípadě MSD žádná opční doložka neexistuje.

Poté, co neuspěla opravdová obligatorní jurisdikce, naděje se upnuly k systému obligatorní jurisdikce, který měl být vytvořen na základě opční doložky. Předpokládalo se, že prostřednictvím prohlášení se vytvoří skupina států, které budou mezi sebou v podobném vztahu, jako jsou subjekty vnitrostátního práva podléhající téže jurisdikci, a že se tato skupina bude postupně rozšiřovat.

\subsection{CHARAKTERISTIKA SDMS A JEHO ROZHODOVACÍ ČINNOST Z HLEDISKA SPORNÉ JURISDIKCE}

Pokud šlo o personální jurisdikci, platilo - stejně jako dnes - že stranou sporného řízení mohou být jen státy. Pokud šlo o přístup ke Dvoru, byl Dvůr otevřen členům Společnosti národů, dále státům uvedeným v př́loze Paktu Společnosti národů a za určitých podmínek pak i dalším státům. SDMS (oproti MSD) nebyl součástí, resp. orgánem Společnosti národů. Jeho Statut byl formálně zcela nezávislý na Paktu Společnosti národů. Členství ve Společnosti neznamenalo, že se stát bez dalšího stává stranou Statutu.

14 Pro úplnost lze dodat, že byla projednána i možnost, aby za určitých podmínek měli př́stup ke Dvoru také jednotlivci, jež se však ukázala jako nereálná. (Advisory Committee of Jurists, Procès-verbaux, pp. 204-217).

15 Mezi zastánce obligatorní jurisdikce patřil i Bernard Loder, budoucí první předseda SDMS. Ten uvedl, že musí být uznáno právo jedné strany vznést žalobu proti jiné straně bez jejího souhlasu a že k založení jurisdikce není nutná dohoda stran sporu. Právě v tom spatřoval rozdíl oproti arbitráži. (Advisory Committee of Jurists, Procès-verbaux, p. 224).

16 Řada států koncepci obligatorní soudní pravomoci sice podporovala, jiné v ní však spatřovaly př́lišné omezení své suverenity. Objevily se rovněž námitky, že by takové ustanovení bylo v rozporu s - dle některých názorů - dispozitivní povahou článků 12 a 14 Paktu Společnosti národů. (ALEXANDROV, S. Reservations in Unilateral Declarations Accepting the Compulsory Jurisdiction of the International Court of Justice. Martinus Nijhoff Publishers, 1995). 
Materiální jurisdikce - stejně jako dnes - plně závisela na souhlasu sporných stran a zakládala se na obdobných titulech (zvláštní dohoda o předložení konkrétního sporu Dvoru, jednostranné prohlášením o přijetí obligatorní jurisdikce, doložka mezinárodní smlouvy i princip forum prorogatum).

Doložku o jurisdikci SDMS obsahovala řada bilaterálních a multilaterálních smluv (včetně tak významných, jako byly smlouvy mírové či všechny mandáty Společnosti národů).

Přijetím opční doložky o přijetí obligatorní jurisdikce Dvora, která byla připojena ke Statutu, stát - obdobně jako dnes - prrijímal jurisdikci Dvora ve vztahu ke kterémukoli jinému státu, který učinil stejný závazek. Obdobným mechanismem státy mohly přijmout jurisdikci Dvora na základě Generálního aktu o pokojném řešení mezinárodních sporů ze dne 26. záŕí 1926. V roce 1938 platil závazek přijetí jurisdikce na základě opční doložky pro 38 států a 33 států takto zavazoval Generální akt o pokojném řešení mezinárodních sporů. ${ }^{17}$

Instrumentů (smluv a jednostranných aktů), jimiž státy ve vztahu k určitým kategoriím sporů přijímaly jurisdikci Dvora, existovalo několik set. Tím byly do značné míry rozptýleny pochybnosti, zda vůbec může stálý mezinárodní soud prakticky a efektivně fungovat. ${ }^{18}$

SDMS byl nadán - stejně jako MSD - pravomocí rozhodovat o své jurisdikci (viz poslední odstavec čl. 36 Statutu SDMS: „V př́padě sporu o tom, zda Soudní dvưr jest př́slušný, rozhodne Soudní dvuir "19). V období od roku 1922 do roku 1940 Stálý dvůr mezinárodní spravedlnosti řešil celkem 29 sporných př́ípadů, ${ }^{20}$ prričemž sedmkrát rozhodoval o své jurisdikci.

Poprvé SDMS rozhodoval o své jurisdikci ve věci The Mavrommatis Palestine Concessions (Greece v. Great Britain) (1924). ${ }^{21}$ Tento rozsudek je zajímavý z řady důvodů. Byl zde vyložen pojem sporu. Byla tu definována podstata diplomatické ochrany. A v neposlední řadě se zde začal formovat samotný procesní postup řízení vedoucí $\mathrm{k}$ rozhodnutí Dvora o vlastní jurisdikci.

Řecká vláda se v žalobě proti Velké Británii jakožto mandátní mocnosti pro Palestinu jako základu jurisdikce, dovolávala se mimo jiné kompromisní doložky obsažené v Mandátu. Britská vláda po obdržení žaloby sdělila Dvoru, že se „cití nucena vznést námitku proti jeho jurisdikci“. Tehdejší procesní pravidla ovšem nestanovila, jak při námitce nepř́íslušnosti Dvora postupovat. Na britskou námitku řecká vláda odpověděla replikou a Dvůr poté konstatoval mimořádně široký dopad námitky a nutnost jejího řešení předtím, než přikročí k projednávání merita věci.

17 The Permanent Court of International Justice: its Constitution and Work. Trilingual book (English, Spanish, French), first published in 1939, republished in 2012, dostupné na: http://www.icj-cij.org/pcij/serie other/cpji-pcij.pdf.

18 Jak se uvádí na webových stránkách MSD: http://www.icj-cij.org.

19 Č. 124/1922 Sb.z.n.

20 To je údaj, který na svých oficiálních webových stránkách uvádí MSD (http://www.icj-cij.org/court /index.php?p1=1\&p2=1\#Permanent). Rosenne uvádí 32 rozhodnutí ve sporných věcech (ROSENNE, S. The World Court: What it is and how it works. 4th ed., Martinus Nijhoff Publishers, 1989).

21 The Mavrommatis Palestine Concessions, Series A. - No. 2, August 30th, 1924. 
Mimo jiné bylo třeba určit, zda se jedná o spor (první podmínka) mezi mandátní mocností a jiným členem Společnosti národů (druhá podmínka). V rámci posuzování první podmínky Dvůr vyslovil dnes „klasickou“ definici sporu.22 V rámci posuzování, zda byla splněna druhá podmínka, Dvůr vymezil podstatu diplomatické ochrany a zahrnul tyto př́ípady do své jurisdikce. Předmětný spor byl totiž původně sporem jednotlivce s cizím státem. Dvůr uvedl: „Tím, že se stát ujme záležitosti svého občana a uchýlí se k diplomatickým krokuim nebo $k$ mezinárodnímu soudnímu ř́zení svým jménem, uplatňuje tento stát ve skutečnosti svoje práva - své právo zajistit, v osobě svého občana, dodržování pravidel mezinárodního práva." 23

A především se zde začalo rodit řízení o předběžné námitce nepříslušnosti. Dvưr konstatoval, že Statut ani Jednací ŕád neobsahují pravidlo pro postup v př́ípadě námitky nepř́íslušnosti Dvora in limine litis. ${ }^{24} \mathrm{~A}$ dospěl k závěru, že je třeba, aby se před vynesením rozsudku ve věci samé ujistil, že jeho jurisdikce se zakládá na př́slušné kompromisní doložce a nestačí pouhý předběžný závěr. Tak byla založena praxe samostatného rozhodování o jurisdikci rozsudkem vydaným v předběžné fázi řízení, kterou SDMS $\mathrm{v}$ dalších řízeních zpřesnil a která nalezne písemné zakotvení až mnohem později, v Jednacím řádu MSD.

Z dalších případů lze výslovně zmínit například př́ípad Mavrommatis Jerusalem Concessions(1925), ${ }^{25} \mathrm{kde}$ se poprvé uplatnil princip forum prorogatum, nebo rozsudek ve věci Phosphates in Morocco (Italy v. France) (1938). ${ }^{26}$ Zde Dvůr přijal stěžejní zásadu jurisdikce ratione temporis, když shledal, že nemá jurisdikci, nebot' prohlášení připojené k opční doložce, jímž Francie přijala jurisdikci ve vztahu ke sporům následujícím po ratifikaci prohlášení, bylo ratifikováno v roce 1931, přičemž skutečnosti, jež daly vzniknout předmětnému sporu, nastaly nesporně dříve.

Závěrem lze k působení SDMS konstatovat, že svou rozhodovací praxí ohledně vlastní jurisdikce zformoval elementární principy, které MSD dodnes aplikuje a rozvíjí. (Tak např́ílad bylo etablováno právo činit výhrady k opčním prohlášením, ${ }^{27}$ do pravomoci Dvora byly zahrnuty př́pady diplomatické ochrany, byl potvrzen a rozvinut princip konsensuální jurisdikce, byl zaveden princip forum prorogatum a v neposlední řadě se zformoval procesní rámec rozhodování o jurisdikci - tj. cesta rozsudku o předběžné námitce nepř́slušnosti Dvora.) Role SDMS v tomto ohledu byla naprosto zásadní. SDMS přitom svoji pravomoc nejen právně upřesňoval, ale především aktivně vykonával (a to i v prípadech politicky citlivých).

22 „A dispute is disagreement on a point of law or fact, a conflict of legal views or of interests between two persons. “ (The Mavrommatis Palestine Concessions, P.C.I.J., Series A. - No. 2, August 30th, 1924, p. 11).

23 The Mavrommatis Palestine Concessions, P.C.I.J., Series A. - No. 2, August 30th, 1924, p. 12.

24 The Mavrommatis Palestine Concessions, P.C.I.J., Series A. - No. 2, August 30th, 1924, p. 16.

25 Mavrommatis Jerusalem Concessions, P.C.I.J., Series A. - No. 5, March 26th, 1925.

26 Phosphates in Morocco (Preliminary Objections), P.C.I.J., Judgment of June 14th, 1938, Series A/B.

27 Dokonce do té míry, že při přípravě statutu nového soudu experti řeknou, že ani není třeba tuto možnost zakotvit v psaném právu. 


\subsection{VZNIK PSANÝCH PRAVIDEL O SPORNÉ JURISDIKCI MEZINÁRODNÍHO SOUDNÍHO DVORA}

V rámci př́íprav nové univerzální mezinárodní organizace, která se začala formovat $\mathrm{v}$ průběhu 2 . světové války, se opět otevřela otázka parametrů nového soudního orgánu, včetně vymezení jeho pravomoci. Př́ipravou návrhu statutu nového soudu pro Konferenci v San Francisku byl pověřen Výbor právníků ze 44 zemí, který byl svolán v dubnu 1945 do Washingtonu (Washington Committee of Jurists).

Nejprve bylo třeba zvolit mezi SDMS a vytvořením nového soudu. Bylo rozhodnuto, že bude zřízen soud nový, ovšem s využitím zkušeností SDMS. ${ }^{28}$ Vedly $\mathrm{k}$ tomu politické zájmy na diskontinuitě soudů, nikoli skutečnost, že by SDMS byl hodnocen jako nevyhovující.

Další klíčovou otázkou bylo vymezení jurisdikce: bude tentokrát v pravém smyslu obligatorní? Washingtonský právní výbor nedospěl k jednoznačnému závěru a předložil Konferenci v San Francisku dva alternativní návrhy. První varianta v podstatě kopírovala čl. 36 Statutu SDMS. Druhá varianta stanovila obligatorní jurisdikci Dvora pro všechny právní otázky.

Konference v San Francisku uložila posouzení návrhu ustanovení o jurisdikci Výboru IV/1, jenž zř́́dil Podvýbor IV/1/D. Ten měl rozhodnout, který z návrhů jurisdikce bude vzat za základ pro další jednání a práce. Měl nakonec na výběr mezi třemi variantami: zmíněnými dvěma předloženými Washingtonským výborem a navíc návrhem Nového Zélandu s koncepcí striktně obligatorní jurisdikce.

Podvýbor se rozhodl pro tradiční cestu, tedy pro zachování konsensuální jurisdikce. Většina delegátů sice emocionálně podporovala obligatorní jurisdikci, ale existovaly obavy, aby striktní mechanismus jurisdikce nezabránil schválení textu Charty a Statutu. (Zarytými odpůrci obligatorní jurisdikce totiž byly Spojené státy americké a Sovětský svaz. $)^{29}$

Je prríznačné, jak poznamenává Nagendra Singh (soudce a poté i předseda MSD), že ani v tak kritických dobách lidské historie nebylo upřednostněno obligatorní soudní řešení sporů. ${ }^{30}$

Nové ustanovení čl. 36 Statutu MSD obsahovalo oproti předchozímu pouze dvě nevelké obsahové změny. ${ }^{31}$ Skutečnost, že ustanovení Statutu SDMS a MSD o jurisdikci jsou prakticky identická, umožnila, aby nový soud mohl plně navázat na výklad těchto ustanovení, který provedl jeho předchůdce. Nadto byla do Statutu MSD zakotvena ustanovení, která určila, že jurisdikce, kterou státy přijaly ve vztahu k SDMS, přechází na MSD (čl. 36 odst. 5 a čl. 37 Statutu MSD).

V důsledku toho lze říci, že jurisdikce Světového soudu, její historie i současnost představuje jediný, dodnes probíhající „prríběh“, který se začal psát v roce 1920 a který

28 ZIMMERMAN, A. - OELLERS-FRAHM, K. - TOMUSCHAT, C. - TAMS, C. J. The Statute of the International Court of Justice: A commentary. 2nd ed. Oxford: Oxford University Press, 2012, s. 639 a nás1.

29 Tamtéž, s. 640.

30 NAGENDRA S. The Role and Record of the International Court of Justice, Martinus Nijhoff Publishers, 1989, s. 10.

31 Došlo k vypuštění slov „or any of the classes“ z druhého odstavce a k doplnění pátého odstavce ohledně prohlášení o př́ijetí jurisdikce ve vztahu k SDMS. 
prošel určitým vývojem, má své kapitoly i zásadní zlom v podobě zániku původního soudu a vzniku soudu nového, ale vyznačuje se pozoruhodnou kontinuitou. Tento mechanismus přetrval již století, přestál všechny historické změny, jimiž mezinárodní společenství během této doby procházelo, a přestože nenaplnil všechna očekávání, která stála u jeho zrodu, nezhroutil se a ani z hlediska svého účelu a reálných možností fatálně neselhal.

\section{K POVAZE PRÁVNÍHO RÁMCE JURISDIKCE MSD}

Konstitucionální pravidla jsou smluvní povahy. Jsou obsažena v Chartě OSN a ve Statutu MSD, který je její nedílnou součástí. Tato pravidla jsou závazná nejen pro státy, resp. procesní strany, ale též pro samotný Dvưr.

V Chartě OSN jsou pro jurisdikci Dvora relevantní zejména články 92 až 95 z Kapitoly IV, která upravuje MSD jakožto hlavní soudní orgán OSN. Čl. 94 Charty OSN a čl. 59 Statutu MSD ve spojení s úpravou jurisdikce Dvora vymezují dva stěžejní principy soudního mechanismu OSN. Zaprvé, soudní pravomoc je nezávazná, tedy plně dobrovolná, a zadruhé, je-li rozhodnutí Dvora přijato, je pro dotčené strany závazné.

Obecnějši rámec, v němž MSD funguje, představuje VI. kapitola Charty OSN, která upravuje pokojné řešení sporů. $V$ této souvislosti je vhodné zmínit čl. 36 odst. 3 Charty OSN, jenž se jurisdikce MSD dotýká pouze zdánlivě. Ukládá Radě bezpečnosti, aby přri doporučování vhodného řešení sporu znesvářeným státům přihlížela k tomu, že ,spory právní povahy by strany měly vznášet na Mezinárodní soudní dvůr podle ustanovení jeho statutu“, je však pouze proklamativní, neplyne z něj žádná právní povinnost.

Ustanovení Statutu MSD týkající se jeho jurisdikce jsou obsažena v článcích 34 až 37, Kapitola II.

Procesní pravidla, včetně těch spojených s jurisdikcí Dvora a jejím určováním, jsou zakotvena v Jednacím řádu MSD. Dvưr přijímá svoje procesní pravidla (Jednací rád) na základě čl. 30 Statutu MSD a sám je i mění.

Pravidla o jurisdikci obsažená v pramenech smluvního práva jsou stručná. Dvưr je od samého počátku existence SDMS musí svou rozhodovací praxí nejen interpretovat, ale i dotvářet a dokonce vytvářet nová (pro něž lze oporu ve Statutu nalézt jen velmi obtížně). Značný význam judikatury je podstatným rysem této oblasti.

„Výkon soudnictví, at již v oblasti vnitrostátni nebo mezinárodní, se bytostně dotýká samého srdce právniho života. Má tudiž moc a vliv, aby se při výkonu spravedlnosti vytvořil potřebný rytmus a harmonie, jež poskytuji životně důležitou podporu pro zdraví společenského života celého společenství. Integrita soudu při výkonu soudnich funkcí tak není ničím menšim, než jedním ze základních pilírù civilizace." (Nagendra Singh, soudce a v letech 1985 až 1988 předseda MSD) ${ }^{32}$ V tomto smyslu lze zde uvést ohledně předmětné judikatury obecnou poznámku.

Judikatura (obou soudů) v oblasti jurisdikce na sebe v zásadě plynule navazuje a lze říci, že požadavek základní integrity naplňuje. Nicméně to neznamená, že by se v ní ne-

32 NAGENDRA, The Role and Record of the International Court of Justice, s. 173. 
objevovaly žádné vnitřní rozpory a logické nesrovnalosti. Některé inherentní nedostatky (o nichž bude řeč níže) ostatně provázejí současný mechanismus sporné jurisdikce $\mathrm{v}$ důsledku jeho povahy, což se nutně musí projevit také v kasuistice. Ale i z obsahového hlediska lze - byt' je to spíše výjimečné - nalézt v judikatuře Dvora vnitřní rozpory, pro jejichž odůvodnění se hledá právní argumentace velmi obtížně (viz dále k rozsudkům k čl. 35 Statutu MSD).

\section{PROCESNÍ RÁMEC JURISDIKCE V JEDNOTLIVÝCH ŘÍZENÍCH}

Uplatňování jurisdikce (a zejména rozhodování o ní) se technicky realizuje v určitém procesním rámci.

Předně je nutno vymezit právní základ jurisdikce při zahájení řízení. Řízení může být zahájeno v zásadě dvojím způsobem. Prvním z nich je zvláštní dohoda (kompromis), kterou strany předloží Dvoru. Zvláštní dohoda je sama o sobě základem jurisdikce. V ostatních př́padech je řízení zahajováno žalobou (at’ už se žalobce dovolává coby základu jurisdikce prohlášení o prrijetí obligatorní jurisdikce, doložky mezinárodní smlouvy, prrípadně více smluv, či kombinace obou titulů). Jednací rád (čl. 38) ukládá žalobci, aby v žalobě co nejpodrobněji specifikoval právní základ, na kterém má být jurisdikce založena.

Pokud žalovaná strana základ jurisdikce uplatňovaný žalobcem neuznává, podá námitku nepř́islušnosti Dvora, následně Dvưr přeruši rrízení ve věci samé a je zahájeno incidenční řízení, tj. řízení o předběžné námitce. Ve výsledku Dvưr bud' námitku akceptuje, nebo ji zamítne, anebo usoudí, že námitka nemá výlučně předběžný charakter. V každém př́ípadě musí rozhodnout rozsudkem.

K tomu, aby Dvůr mohl meritorně projednat daný spor, musí být splněny dvě podmínky: př́slušnost Dvora (jurisdikce) a přípustnost řízení. Řízení o předběžné námitce (čl. 79 Jednacího řádu) slouží $\mathrm{k}$ tomu, aby byly odstraněny pochybnosti ohledně splnění těchto dvou podmínek před tím, než Dvůr začne projednávat meritum. Obě otázky se obvykle projednávají v rámci řízení o předběžné námitce.

Příslušnost Dvora a př́ípustnost řízení je však třeba od sebe odlišovat. Zatímco (ne) př́slušnost Dvora není v podstatě ničím jiným, než otázkou souhlasu sporných stran $\mathrm{s}$ jurisdikcí a $\mathrm{v}$ rámci řízení o námitce nepř́íslušnosti Dvůr pouze přezkoumává existenci uděleného souhlasu sporných stran a jeho rozsah, otázka prŕpustnosti (angl. admissibility, fr. recevabilité) zahrnuje výrazně širší spektrum otázek. Vztahuje se k jiným požadavkům mezinárodního práva, které mohou vyplývat bud' z pravidel obecného mezinárodního práva, nebo ze zvláštních dohod mezi dotčenými státy (např. vyčerpání vnitrostátních opravných prostředků při výkonu diplomatické ochrany) nebo ze zvláštních dohod mezi dotčenými státy (např. závazek předložit určitý spor nebo spory určité kategorie arbitráži). Jenomže, jak říká Tomuschat, , i když teoreticky je jednoduché rozlišovat mezi jurisdikcí a př́pustností, v praxi se může nalezení přesné hranice ukázat jako extrémně obtižné". Jako př́klad uvádí dohodu stran o tom, že určitý typ sporů budou $\mathrm{k}$ řešení př̀edkládat výhradně arbitráži. Taková dohoda by pak mohla být na překážku 
přípustnosti řízení, zatímco stejná podmínka obsažená v prohlášení o přijetí obligatorní jurisdikce by způsobovala nepř́islušnost Dvora. ${ }^{33}$

V rámci procesní problematiky je vhodné zmínit ještě jedno rozlišení dvou typů jurisdikce, které lze označit jako substantivní a incidenční jurisdikci. Substantivní jurisdikce představuje pravomoc Dvora rozhodovat v meritu věci.

Incidenční jurisdikce ${ }^{34}$ se vztahuje k ostatním otázkám, o nichž je potřeba rozhodnout před rozhodnutím o meritu, př́padně i před rozhodnutím o jurisdikci podle čl. 36 odst. 6 Statutu MSD. Sem spadá např́íklad pravomoc Dvora řídit samotné řízení, rozhodovat o předběžných opatřeních, rozhodovat o vstupu třetích stran do řízení apod. Obecně platí, že je-li dána substantivní jurisdikce pro řízení, incidenční jurisdikce k ní přistupuje automaticky. Jinými slovy přistupuje $\mathrm{k}$ hlavnímu řízení a k tomu, aby byla založena, není nutný souhlas stran. ${ }^{35}$ Spadá sem např́iklad také jurisdikce pro výklad a revizi rozsudku. ${ }^{36}$ Incidenčním řízením je i řízení o předběžné námitce.

\section{ROZHODNUTÍ O OTÁZCE JURISDIKCE (COMPÉTENCE DE LA COMPÉTENCE) A SPECIFICKÉ ZPU゚SOBY POSUZOVÁNÍ JURISDIKCE}

\section{1 ČLÁNEK 36 ODST. 6 STATUTU MSD, JEHO VÝZNAM A DŮSLEDKY}

Normativním ohniskem rozhodování o sporné jurisdikci je ustanovení čl. 36 odst. 6 Statutu MSD. To stanoví, že ,,[v]znikne-li spor o př́slušnosti Dvora, rozhodne Dvi̊r". Toto ustanovení svěřuje Dvoru velmi významnou pravomoc. V př́padě sporu o jurisdikci rozhoduje Dvưr, a nikoli státy, které jsou stranami dotčeného sporu.

Sám Dvůr se k principu compétence de la compétence, tedy k pravomoci, kterou mu uděluje čl. 36 odst. 6 Statutu, podrobně vyjádřil ve věci Nottebohm (1954). Zde odvodil svou pravomoc rozhodovat o své jurisdikci nejen z čl. 36 odst. 6 Statutu, ale i z obecného mezinárodního práva. ${ }^{37}$

V momentě, kdy se uplatní toto pravidlo, státy, jež byly až do okamžiku zahájení ŕízení naprostými ,pány jurisdikce“, nad ní pozbývají kontrolu. Dvưr v rámci řízení o námitce nepř́íslušnosti sám vykládá příslušné instrumenty, resp. projevy vůle, jimiž sporné strany přijaly jeho jurisdikci, a z tohoto výkladu dovozuje existenci své jurisdikce a její rozsah. Stát, který neuspěl s námitkou nepř́islušnosti, už nemá žádný prostředek, jak se jurisdikci ubránit, a bude vázán jak rozsudkem o jurisdikci, tak i rozsudkem ve věci samé. Aktuální vůle státu ohledně jurisdikce Dvora pro daný spor v určitém okamžiku

33 ZIMMERMAN - OELLERS-FRAHM - TOMUSCHAT - TAMS, The Statute of the International Court of Justice: A commentary, s. 698.

34 Incidenční jurisdikce by se dala také označit jako „vedlejší“ nebo „,doprovodná“, ale budu se držet termínu, který je v procesním právu obecně ustálen, i když v češtině vyznívá poněkud cizorodě.

35 ZIMMERMAN - OELLERS-FRAHM - TOMUSCHAT - TAMS, The Statute of the International Court of Justice: A commentary, s. 656.

36 Tamtéž.

37 Nottebohm case (Preliminary Objection), Judgement of November 18th, 1953, I.C.J. Reports 1953, p. 111 (s. 119). 
přestává být relevantní. Cum grano salis, okamžikem zahájení řízení „sklapne jurisdikční past".

Závaznost rozsudků, jimiž Dvůr určuje svou jurisdikci (pochopitelně deklaratorně), se opírá o silný právní základ (přímo o čl. 94 odst. 1 Charty OSN) a v praxi nebývá zpochybňována. (Nejznámější výjimkou byl případ, kdy USA odmítly přijmout rozsudek ve věci Nicaragua a následně v Radě bezpečnosti vetovaly návrh rezoluce, která měla prosazení tohoto rozsudku zajistit.)

Vedle pravidla, že o své pravomoci rozhoduje sám Dvůr, je druhým klíčovým principem stanovení rozhodného okamžiku, k němuž je jurisdikce Dvora (její existence a rozsah) posuzována. Tato dvě pravidla se doplňují a jsou vzájemně provázána.

V období od vzniku sporu do okamžiku jeho rozhodnutí dochází ke změnám okolností relevantních pro založení př́islušnosti Dvora (strana sporu odvolá dříve udělený souhlas s jurisdikcí, uplyne platnost takového souhlasu nebo se změní jiné relevantní okolnosti). Statut MSD žádné kritérium, podle něhož se má v takových případech postupovat, výslovně nedefinuje. Dvưr byl proto nucen je určit sám.

Jen teoreticky (a i tak stěží) si lze představit řešení spočívající v požadavku, aby byly splněny podmínky pro založení jurisdikce po celou dobu rrízení. To by činnost Dvora zcela ochromilo, nebot' strana, jejíž neúspěch by průběh procesu naznačoval, nebo pro niž by proces představoval nepřijatelné riziko, by odmítla jurisdikci Dvora před vydáním rozsudku.

Pravidlo určující okamžik rozhodný pro posouzení existence a rozsahu jurisdikce spočívá $\mathrm{v}$ tom, že pokud je jurisdikce MSD založena $\mathrm{k}$ datu podání žaloby, přesněji byla-li jednou založena ( $\mathrm{k}$ čemuž ve výjimečných př́ipadech může dojít i později), další skutečnosti či okolnosti, k nimž poté dojde, na ni nebudou mít vliv.

Dvůr definoval rozhodný okamžik v př́ípadu Nottebohm (Liechtenstein v. Guatemala). Dne 17. prosince 1951 podalo Lichtenštejnsko žalobu proti Guatemale a dovolávalo se prohlášení podle čl. 36 odst. 2 Statutu MSD, jimiž oba státy přijaly obligatorní jurisdikci. Guatemala podala námitku nepř́slušnosti Dvora s tím, že platnost prohlášení, kterým přijala jurisdikci na časově omezené období pěti let, uplynula již několik týdnů po podání žaloby a každopádně dlouho před tím, než by Dvůr spor př́ípadně vyřešil. Dvůr shledal, že uplynutí pětiletého období, na které Guatemala přijala jeho př́slušnost, dne 26. ledna 1952 nemůže mít vliv na př́slušnost Dvora k projednání žaloby podané dne 17. prosince 1951. Přitom vyslovil větu, na kterou se opakovaně odvolává ve svých pozdějších rozhodnutích: „Vnějši okolnost, jakou je zánik prohlášení z duvodu vypršení jeho doby platnosti nebo jeho vypovězení, nemüže zbavit Dvůr jurisdikce již jednou založené." "38

Toto pravidlo pak bylo upřesněno ve věci Right of Passage over Indian Territory (Portugal v. India), kde Dvůr doplnil, že se tento princip vztahuje jak na úplné, tak i částečné vypovězení opčního prohlášení. ${ }^{39}$

38 Nottebohm case (Preliminary Objection), Judgment of November 18th, 1953: I.C.J. Reports 1953, p. 111 (s. 123).

39 Case concerning Right of Passage over Indian territory (Preliminary Objections), Judgment of November 26th, 1957, ICJ Records 1957, p. 125 (viz s. 21). 
Výše zmíněné pravidlo lze parafrázovat tak, že je-li dána jurisdikce $\mathrm{k}$ datu podání žaloby, resp. k datu zahájení rízení, Dvưr bude oprávněn rozhodnout ve věci samé a žalovaný se nemůže jurisdikci vyhnout.

Pokud ovšem k datu podání žaloby jurisdikce Dvora dána není, avšak později je tento nedostatek zhojen, Dvůr bude v ř́zení oprávněn meritorně rozhodnout (princip zvaný forum prorogatum).

Pravidlo, které lze - s výhradou pozdějšího přijetí jurisdikce na základě principu forum prorogatum - shrnout jako „,k datu podání žaloby“ doplňuje pravidlo, že „,vznikne-li spor o príslušnosti Dvora, rozhodne Dvưr", a spolu s ním významně omezuje pole konsensu státu na úseku jurisdikce Dvora. Definuje totiž okamžik, kdy se zmíněná „jurisdikční past“ zavírá.

\section{2 ČLÁNEK 53 ODST. 2 STATUTU MSD ANEB „PRÁZDNÝ STU゚L V JEDNACÍ SÍNI“}

Je na místě stručně zmínit také situaci, kterou anglická terminologie označuje jako non-appearance. Jde o situaci, kdy se žalovaná strana řízení neúčastní a implicitně jurisdikci Dvora popírá. Neúčast žalovaného však nebrání a nemůže Dvoru bránit pokračovat v řízení. Pokud by se stát mohl vyhnout rozsudku tím, že by žalobu a následné ř́zení prostě ignoroval, obligatorní jurisdikce $\mathrm{v}$ širším smyslu by ztratila smysl. Dvůr má proto i v těchto př́padech právo, resp. povinnost meritorně rozhodnout, ale podléhá to určitým podmínkám.

Statut MSD tuto situaci předvídá v čl. 53 odst. $2 .{ }^{40}$ Vyplývá z něj, že pokud se žalovaná strana řízení neúčastní, Dvůr na žádost žalobce může rozhodovat o uplatňovaných nárocích, avšak musí dříve, než přistoupí $\mathrm{k}$ meritu věci, ex offo přezkoumat, zda má jurisdikci. Dvůr musí - při zachování nestrannosti - projednat i argumenty, které by žalovaný mohl vznést, kdyby se ř́zení účastnil, a to jak v otázkách merita, tak i ve vztahu k otázkám prŕpustnosti a jurisdikce. Je to důsledek principu konsensuální jurisdikce.

\subsection{SPECIFIKA POSUZOVÁNÍ JURISDIKCE PŘI ROZHODOVÁNÍ O ULOŽENÍ PŘEDBĚŽNÝCH OPATŘENÍ}

\section{„,Nehodlám do věci vnášet jasno, ale naopak zmatek. “ (Umberto Eco)}

V souvislosti s posuzováním jurisdikce je namístě zmínit situaci, která vlastně pravým posouzením jurisdikce není. Jde o případy, kdy Dvưr ukládá předběžná opatření ve fázi řízení, kdy o jurisdikci ještě není rozhodnuto (je projednávána předběžná námitka nepříslušnosti Dvora, případně je indikováno, že bude námitka nepříslušnosti uplatněna), a současně vyvstává naléhavá potřeba předběžným opatřením na

40 (1) Jestliže se jedna ze stran nedostaví nebo vi̊bec svou při nehájí, může druhá strana žádat, aby Dvůr rozhodl ve prospěch jejích nárokì. (2) Dřive než tak učiní, musí se Dvi̊r přesvědčit, nejen že je príslušný podle článku 36 a 37, ale také, že přednesený nárok je skutkově i právně odůvodněn. 
základě podané žádosti ochránit ohrožený legitimní zájem. ${ }^{41}$ Předběžné opatření může zasáhnout do práv státu, vůči kterému Dvůr, jak se může později ukázat, nemá a od počátku neměl žádnou pravomoc. Statut MSD tento problém neřeší. Dvůr tedy - aby alespoň částečně kompenzoval rizika s tím spojená - vytvořil praxi, kdy před uložením předběžného opatření v této fázi řízení přezkoumá, zda má jurisdikci prima facie, a teprve je-li výsledek tohoto posouzení kladný, předběžná opatření uloží. Vždy však zdůrazňuje, že uložení předběžných opatření v žádném prŕípadě nepředjímá rozhodnutí o otázce jurisdikce ve věci samé. Zároveň Dvưr výslovně připouští, že jeho jurisdikce není při rozhodnutí o předběžných opatřeních vyřešena. ${ }^{42}$ Poprvé tuto formulaci použil již v roce 1952 ve svém rozsudku ve věci Anglo - Iranian Oil Co. Preliminary Objection. ${ }^{43} \mathrm{~V}$ tomto prŕípadě byla předběžná opatření uložena. Dvưr nejprve konstatoval, že je dána jeho jurisdikce prima facie, avšak $\mathrm{v}$ dalším průběhu řízení dospěl $\mathrm{k}$ rozsudku, že ve věci samé není príslušný. Případy, kde byla uložena předběžná opatření v předběžné fázi po podání námitky nepř́islušnosti Dvora nebo po indikaci, že námitka nepř́slušnosti bude podána, je řada. ${ }^{44}$

Problém (ač spíše teoretické povahy) spočívá otázce, z jakého titulu je stát, jemuž bylo předběžné opatření uloženo, povinen se závaznému rozhodnutí o předběžném opatření podrobit, pokud jurisdikci Dvora nepřijal, což se následně potvrdí rozsudkem; Dvůr tedy nebyl př́slušný od samého počátku.

Tento systémový nedostatek je ze strany Dvora - ovšem pouze částečně - překlenován dvěma prostředky: zaprvé zjištováním jurisdikce prima facie před rozhodnutím o uložení předběžných opatření a zadruhé případným zrušením uložených předběžných opatření, jakmile Dvưr dospěje k rozhodnutí, že ve věci samé není př́slušný. Posouzení jurisdikce prima facie však zjevně nestačí a zrušení rozhodnutí, které soud nebyl oprávněn vůbec vydat, rovněž není přesvědčivé. Zdá se, že problém jurisdikce ve vztahu k uložení předběžných opatření ve fázi, kdy není o jurisdikci rozhodnuto, je jedním z inherentních důsledků konsensuální jurisdikce.

\section{JURISDIKCE RATIONE TEMPORIS}

Obecně lze jako jurisdikci ratione temporis označit určení, které události z časového hlediska, resp. která časová období, je daný soud oprávněn posuzovat. V jis-

41 Možnost uložení předběžných opatření je upravena v čl. 41 Statutu MSD a v čl. 73 a 74 Jednacího řádu. Dvůr je ukládá, pokud to okolnosti vyžadují. O jejich uložení lze požádat v kterékoli fázi rrízení a opatření pak zůstávají v platnosti, dokud řízení neskončí, príípadně dokud nejsou zrušena či změněna.

42 Např. Legality of Use of Force (Yugoslavia v. Belgium), Provisional Measures, Order of 2 June 1999, ICJ Reports 1999, p. 124: „on a request for provisional measures the Court need not, before deciding whether or not to indicate them, finally satisfy itself that it has jurisdiction on the merits, yet it ought to indicate such measures unless the provisions invoked by the applicant appear, prima facie, to afford a basis on which the jurisdiction of the Court might be established" (s. 32, odst. 21).

43 Anglo-Iranian Oil Co. Case, Order of July 5th, 1951, I. C. J. Reports 1951, p. 89: ,the indication of such measures in no way prejudges the question of the jurisdiction of the Court to deal with the merits of the case and leaves unaffected the right of the Respondent to submit arguments against such jurisdiction" (s. 93).

44 Např́iklad „Interhandel“, „Fisheries Jurisdiction“ (Federal Republic of Germany v. Iceland) a (United Kingdom of Great Britain and Northern Ireland v. Iceland), tzv. ,jugoslávské př́pady“. 
tém smyslu sem spadá i určení okamžiku rozhodného pro posouzení jurisdikce. Jurisdikce Dvora ratione temporis se vždy váže k okolnostem rozhodným bud' pro otázky ratione personae nebo ratione materiae.

$\mathrm{V}$ obecné rovině není pravomoc Dvora ratione temporis nijak omezena a dopadá retroaktivně i na spory, které vznikly před jejím prrijetím, pokud to stát výslovně neomezí. Např́klad ve věci Ambatielos dokonce rozhodoval Dvůr o událostech, které se odehrály dř́ve, než vůbec vznikl. ${ }^{45}$

Státy přijímající jurisdikci Dvora mají právo toto přijetí $\mathrm{v}$ jakémkoli ohledu omezit. $\mathrm{V}$ praxi jsou právě výhrady ratione temporis, zejména $\mathrm{v}$ rámci prohlášení podle čl. 36 odst. 2 Statutu MSD velmi časté, prrímo typické. Jako př́klad lze uvést prohlášení Izraele z roku 1956, jež vyloučilo z jurisdikce Dvora „spory, které vznikly ohledně událostí, k nimž došlo mezi 15. květnem 1948 a 20. červnem 1949““46 Velmi časté jsou výhrady, kdy stát prohlášením o přijetí obligatorní jurisdikce takto přijímá jurisdikci Dvora pouze pro spory, které vzniknou až po jejím príijetí.

Prvním př́padem, v němž Dvůr definoval klíčový princip rozhodování o jurisdikci ratione temporis, byl výše citovaný rozsudek SDMS ve věci Phosphates in Morocco, $\mathrm{v}$ němž konstatoval, že není ratione temporis př́slušný, nebot' $\mathrm{k}$ událostem, jichž se týkal předmětný spor, došlo před ratifikací opčního prohlášení Francie, přičemž toto prohlášení se vztahovalo na spory ohledně situací či skutečností následujících po ratifikaci.

$\mathrm{Z}$ novějších prrípadů, kde aspekt ratione temporis sehrál rozhodující roli, lze jako zajímavý př́íklad uvést rozsudek Certain Property (Liechtenstein v. Germany), Preliminary Objections. ${ }^{47}$ Lichtenštejnsko se jako na právní základ jurisdikce odvolalo na čl. 1 Evropské úmluvy o mírovém urovnávání sporů ze dne 29. dubna 1957, jenž stanoví, že „Vysoké smluvní strany předloži Mezinárodnímu soudnímu dvoru k rozhodnutí všechny právní spory, které mezi nimi vyvstanou.“ Čl. 27 (a) této úmluvy stanoví, že její ustanovení se nevztahují mj. na spory týkající se skutečností či situací, které nastaly dříve, než Úmluva vstoupila $\mathrm{v}$ platnost mezi stranami sporu, $\mathrm{k}$ čemuž $\mathrm{v}$ tomto př́ípadě došlo 18. února 1980. Jako předmět sporu žalobce vymezil rozhodnutí německých vnitrostátních soudů z roku 1998 a z let pozdějších, která se týkala určitého majetku lichtenštejnských občanů, včetně majetku knížete Františka Josefa II. Lichtenštejnského, konfiskovaného československými orgány na základě Benešových dekretů. Německo vzneslo mimo jiné námitku nepř́slušnosti Dvora (nedostatku jurisdikce) ratione temporis, kde šlo o to, zda se projednávaný spor týká událostí a skutečností spadajících do období před rokem 1980. Dvůr této námitce vyhověl. V odůvodnění rozsudku se odvolal na rozsudky SDMS Phosphates in Morocco a Electricity Company in Sofia and Bulgaria a na vlastní rozsudek ve věci Right of Passage over Indian Territory. Dvůr konstatoval, že text čl. 27 (a) Úmluvy se podstatně neliší od omezení temporální jurisdikce, které byly řešeny ve třech výše uvedených př́padech. Musel tedy posoudit, zda se spor týká událostí spadajících do období před 18. únorem 1980. Nakonec dospěl k závěru, že i když samotný spor mezi Lichtenštejnskem a Německem byl vyvolán rozhodnutími německých soudů z 90. let, zdroj či pravá přičina sporu se ve skutečnosti týká Smlouvy

45 NAGENDRA, The Role and Record of the International Court of Justice, s. 13.

46 Citováno podle NAGENDRA, The Role and Record of the International Court of Justice, s. 13.

47 Certain Property (Liechtenstein v. Germany), Preliminary Objections, Judgment, ICJ Reports 2005, p. 6. 
o vztazích mezi SRN a západními mocnostmi podepsané dne 26. května 1952 v Bonnu a Benešových dekretů. Tudíž není ratione temporis př́slušný k rozhodnutí ve věci samé.

\section{JURISDIKCE A RATIONE PERSONAE}

„MSD je jediným soudním orgánem, který je otevřen všem státům... je tedy kvalifikován k tomu stát se obecným soudem pro celé mezinárodní společenství."

(Hermann Mosler)

\section{1 ÚVODNÍ POZNÁMKA K PERSONÁLNÍ JURISDIKCI}

V mezinárodním právu lze jurisdikci ratione personae definovat jako „okruh aktérů, kteři mohou pred mezinárodním rozhodovacím orgánem vystupovat $v$ pozici procesnich subjektư “ ${ }^{48}$ Ve sporném rrízení před MSD tedy personální jurisdikce vymezuje subjekty oprávněné být stranou sporného řízení. Ve srovnání s materiální jurisdikcí je problematika personální jurisdikce výrazně jednodušší z hlediska právní úpravy i rozhodovací praxe.

Personální jurisdikce MSD má dvě roviny. Zaprvé se jedná o vymezení, jaký typ subjektů může být stranou ve sporném řízení, přičemž těmito subjekty jsou výhradně státy, a zadruhé o určení, za jakých podmínek mají tyto státy ke Dvoru př́stup.

\subsection{STRANOU SPORNÉHO ŘÍZENÍ MOHOU BÝT JEN STÁTY}

Článek 34 odst. 1 Statutu MSD stanoví, že ,[s]tranami ve sporech na Dvi̊r vznesených mohou být jen státy". Toto ustanovení vystihuje podstatu MSD a jeho roli. Je zároveň zdrojem úvah o úloze a budoucnosti Dvora, jakož i značné kritiky z důvodu, že nereflektuje aktuální postavení mezinárodních organizací v dnešním mezinárodním společenství.

\subsection{PŘíSTUP DO SPORNÉHO ŘÍZENÍ}

Ne každý suverénní stát má bez dalšího právo být stranou sporného řízení. Dvůr je státům otevřen pouze při splnění určitých podmínek. Samotný př́stup ke Dvoru neznamená založení jurisdikce Dvora ve vztahu k dotčenému státu. Je to pouze podmínka nutná pro př́ipadné založení jurisdikce ratione materie. De iure existují v současné době tř̌ kategorie států oprávněných být účastníky sporného řízení před MSD: a) členové OSN, b) strany Statutu, které nejsou členy OSN, c) státy, které nejsou stranami Statutu, jimž je Dvůr otevřen za podmínek stanovených Radou bezpečnosti.

48 Závěrečná studie k výzkumnému projektu MZV ČR č. 1/2007 Konkurujicí jurisdikce mezinárodních rozhodovacích orgánů ř řšenému v období 2007-2008 na katedře mezinárodního práva PF UK pod vedením prof. JUDr. Pavla Šturmy, DrSc. (zkrácená verze, dostupná na: http://www.mzv.cz/file/317505/Konkur jurisdikce_zkracena.pdf). 
Aplikace čl. 35 Statutu MSD dala vzniknout sérii problematických rozsudků, které představují výše zmíněný (a zřejmě nejzávažnější) příklad nekonzistentnosti v rozhodování Dvora. V dotčených př́padech bylo sporné, zda Federativní republika Jugoslávie (Srbsko a Černá Hora) je nástupnickým státem bývalé Socialistické federativní republiky Jugoslávie, či přesněji řečeno, jaké je postavení tohoto státu (jehož název se $\mathrm{v}$ rozhodné době měnil) v OSN. Z toho plynoucí otázka, zda má tento stát př́stup ke Dvoru, se stala předmětem rozhodování o jurisdikci ratione personae ve čtyřech př́ípadech, v nichž tento stát vystupoval jako žalující či žalovaná strana. (Jedná se o komplikovanou problematiku, již lze zde prezentovat pouze v náznaku.)

Když Dvůr v roce 1996 rozhodoval o své jurisdikci ve věci Application of the Convention on the Prevention and Punishment of the Crime of Genocide (Bosnia and Herzegovina v. Serbia and Montenegro) - někdy zkráceně označováno jako (Bosnian) Genocide - kde se žalobce odvolával na kompromisní doložku Úmluvy o genocidiu, Dvưr rozhodl, že je př́slušný, přičemž neřešil, zda je překážkou uplatnění čl. 35 odst. 2 Statutu skutečnost, že kompromisní doložka Úmluvy o genocidiu vstoupila v platnost až poté, co Statut MSD nabyl platnosti.

Když pak v roce 2007 rozhodoval ve věci samé, usoudil, že jeho rozsudek o jurisdikci z roku 1996 zakládá res iudicata rovněž ohledně př́stupu k soudu, at’ už na základě čl. 35 odst. 1 , nebo čl. 35 odst. 2 Statutu. ${ }^{49}$

Dalším př́ípadem byl spor, kdy Srbsko a Černá Hora žalovaloy členské státy NATO, tedy př́pad Legality of Use of Force. ${ }^{50}$ Dvůr shledal, že čl. 35 odst. 2 Statutu se vztahuje pouze na smlouvy předcházející vstupu Statutu v platnost, a tedy se kompromisní doložka Úmluvy o genocidiu jako základ jurisdikce uplatnit nemůže. Navíc shledal, že žalobkyně, Federativní republika Jugoslávie, nebyla v době podání žaloby členem OSN, a tudíž nemá př́istup ke Dvoru ani na základě čl. 35 odst. 1 Statutu MSD. Pak by ovšem bylo logické, kdyby Dvůr k témuž dospěl v př́ípadě žalob podaných proti Srbsku i v následujících rozhodnutích. To se však nestalo. Při rozhodování v meritu ve věci (Bosnian) Genocide dospěl k závěru, že je vázán svým rozsudkem o jurisdikci z roku $1996 .{ }^{51} \mathrm{~V}$ dalším případě, ve věci Application of the Convention on the Prevention and Punishment of the Crime of Genocide (Croatia v. Serbia), se Dvůr odchýlil i od principu, že podmínky pro založení jurisdikce musí být splněny při podání žaloby, a shledal, že i když nebyla podmínka př́stupu ke Dvoru podle čl. 35 odst. 1 Statutu MSD splněna $\mathrm{v}$ době podání žaloby, může být tento nedostatek následně zhojen.

V této souvislosti definoval Dvůr princip ohledně zkoumání ex offo podmínek ratione personae. $\mathrm{V}$ př́padě Legality of Use of Force uvedl, že otázka, zda má stát přístup

49 Application of the Convention on the Prevention and Punishment of the Crime of Genocide (Bosnia and Herzegovina v. Serbia and Montenegro), Judgment, I.C.J. Reports 2007, p. 43.

50 Legality of Use of Force (Serbia and Montenegro v. Belgium), (Serbia and Montenegro v. Canada) (Serbia and Montenegro v. France) (Serbia and Montenegro v. Germany) (Serbia and Montenegro v. Italy) (Serbia and Montenegro v. Netherlands) (Serbia and Montenegro v. Portugal) (Yugoslavia v. Spain) (Serbia and Montenegro v. United Kingdom) (Yugoslavia v. United States of America).

51 ZIMMERMAN - OELLERS-FRAHM - TOMUSCHAT - TAMS, The Statute of the International Court of Justice: A commentary, s. 699. 
ke Dvoru, jako strana Statutu nebo na základě čl. 35 odst. 2 Statutu MSD, je mimo dispoziční sféru stran. Ovšem ve věci (Bosnian) Genocide se sám tohoto principu nedržel a omezil se na přezkum předběžných námitek vznesených jugoslávskou vládou.

Výstižně shrnuje situaci Christian Tomuschat, když ríká ,objevil se tak jasný rozpor: Srbsku bylo odepréeno bránit svá práva, která mu údajně byla porušena členskými státy NATO, ale žádná právní překážka nestála $v$ cestě $k$ tomu, aby bylo žalováno". .52

Vzhledem $\mathrm{k}$ tomu, že ve zmíněných rozhodnutích nelze nalézt právní argumentaci, která by naznačené nekonzistentní uvažování Dvora rozumně vysvětlovala, resp. ospravedlnila, nezbývá než podlehnout spekulacím, že jsou založena na motivu jiné než právní povahy (což by přesahovalo vymezené téma tohoto článku). Věc je nicméně o to závažnější, že ve svém důsledku tato situace může vést či dokonce vede $\mathrm{k}$ denegatio iustitiae (jak ostatně výstižně naznačují výše citovaná slova Christiana Tomuschata). ${ }^{53}$

\subsection{MEZINÁRODNÍ ORGANIZACE A SPORNÉ ŘíZENÍ}

Z různých stran dnes zaznívá kritika, že výhradní monopol států na přístup do sporného řízení je přežitkem, který neodpovídá současnému právnímu postavení mezinárodních organizací. Mezi ostré kritiky stávajícího stavu se např́íklad řadí i bývalí předsedové Dvora Jennings a Bedjaoui. Soudce Bejaoui uvedl ve svém projevu na téma „The International Court of Justice: What will its Future be?" adresovaném Valnému shromáždění: „Jurisdikce Dvora ratione personae zamrzla v roce 1922. Dvi̊r je otevřen pouze státům. Dnes, kdy mezivládní organizace dospěly, je důležité umožnit jim přistup do sporného ř́zení. "Naproti tomu Rosenne dospívá k velmi zdrženlivému závěru: „otevření sporného řizení účasti mezinárodních organizací by změnilo charakter mezinárodního soudnictví a není jasné, jaké by to mélo výhody. Zkušenosti od roku 1946 nepodporuji myšlenku, že by mezinárodni organizace potřebovaly přistup do sporného řizení k plněni svých úkolù. " 54

Mám za to, že procesní subjektivitě mezinárodních organizací stojí v cestě při současném uspořádání dvě základní překážky. Předně, státy nemají na této změně zájem. A především, k takové změně by nestačilo jen doplnění dalšího odstavce do čl. 34 či 35 Statutu. Byl by nutné provést systémové zásahy do Statutu MSD i do Charty OSN a upravit nejen procesní subjektivitu, ale např́ílad i otázku sankcí pro prŕípad neprovedení rozsudku.

\subsection{ZÁVĚREČNÁ POZNÁMKA K JURISDIKCI RATIONE PERSONAE}

Lze vysledovat určitý paradox. Materiální jurisdikce Dvora založená na konsensuálním principu je „tak nějak problematická“ ze své povahy. Proto je poněkud překvapivé, že právě v oblasti jurisdikce ratione personae se při bližším pohledu oteví-

52 Tamtéž, s. 700.

53 Tato komplikovaná a citlivá problematika by zasluhovala hlubší rozbor předmětných rozhodnutí, který však z důvodu omezeného rozsahu textu a v zájmu jeho vyváženosti přesahuje možnosti tohoto článku.

54 ROSENNE, S. The World Court: What it is and how it works. 4th ed. Martinus Nijhoff Publishers, 1989, s. 83. 
rají aktuálně nejzávažnější otázky a pochybnosti spojené s úlohou a budoucností Dvora. At' už je to nekonzistentnost $\mathrm{v}$ aplikaci čl. 35 Statutu, nebo otázky spojené s př́padnými reformami Dvora a jeho úlohou do budoucna.

\section{JURISDIKCE RATIONE MATERIAE}

\subsection{MEZINÁRODNÍ SPOR JAKO PODMÍNKA JURISDIKCE DVORA}

Základní podmínkou materiální jurisdikce Dvora ve sporných věcech je existence mezinárodního sporu, který musí splňovat určité znaky.

Pojem sporu vymezil SDMS v roce 1924 ve výše citovaném rozsudku ve věci $M a$ vrommatis Palestine Concessions. Řekl, že ,spor je neshoda ohledně otázky skutkové nebo právní, konflikt právních názorů nebo zájmů mezi dvěma osobami“. Toto vymezení pojmu sporu cituje MSD ve svých rozhodnutích dodnes. ${ }^{55}$ Definice má své nedostatky. Spíše než o uvědomělou, skutečnou právní definici se jedná o prosté vysvětlení, co se obecně rozumí sporem. (Tomuschat např́klad poukazuje na technickou nesprávnost této zrejmě „,věčné“ definice v tom ohledu, že „konflikt zájmư“, který může být založen i pouze na politickém základě, by nesplňoval požadavky, které sám Dvưr aplikuje. $)^{56}$

Judikatura pojem sporu a jeho vlastnosti coby podmínky materiální jurisdikce postupně zpřesňovala. Ve věci South West Africa Dvůr upřesnil, že musí být zřejmé, že „požadavek jedné strany je jednoznačně oponován druhou stranou“ ${ }^{57}$ Ve věci Northern Cameroons uvedl, že: „Dvưr (...) může vynést rozsudek pouze ve vztahu ke konkrétním př́padi̊m, kde existuje v dobè soudního rozhodováni aktuální kontroverze, která zahrnuje konflikt právních zájmů mezi stranami." ${ }^{58}$ Dvůr rovněž konstatoval, že samotná existence sporu je otázkou objektivního určení. ${ }^{59}$ Nestačí, pokud existenci sporu tvrdí jedna strana. ${ }^{60}$

55 Např. Certain Property (Liechtenstein Germany) Preliminary Objections, ICJ Reports (2005), p. 6 (s. 18, odst. 24), Armed Activities on the Territory of Congo (New Application: 2002) (Democratic Republic of Congo v. Rwanda) Jurisdiction and Admissibility. ICJ Reports (2006), p. 6, (s. 40, odst. 90).

56 Když čteme předmětný rozsudek v celé souvislosti, je zřejmé, že tato věta byla výchozím bodem dílčí úvahy, a nikoli jejím produktem. Spíše než o právní definici se jedná o prosté vysvětlení, co se obecně rozumí sporem, od něhož se odvíjí další úvaha. Citovaná věta dle mého názoru navíc ani nemá konstrukci definice, ani z ní jasně nevyplývá vztah mezi první (neshoda ohledně otázky skutkové nebo právní) a druhou částí (konflikt právních názorů nebo zájmů), zda jsou myšleny jako vysvětlení téhož, nebo alternativně nebo jako dva pojmové znaky, jež musí být naplněny zároveň. Dovolím si v této souvislosti heretickou myšlenku, zda by soudci SDMS, pokud by tušili, že právě tato věta z rozsudku obsahujícího 37 stran bude „recyklována“ jejich nástupci ještě za více než devadesát let, vymezení pojmu sporu ještě jednou nezvážili.

57 South West Africa, (Ethiopia v. South Africa, Liberia v. South Africa), Preliminary Objections, ICJ Reports 1962 , p. 319 (s. 328).

58 Northern Cameroons (Cameroon v. United Kingdom), ICJ Reports 1963, p. 15 (s. 33-34).

59 Interpretation of Peace Treaties with Bulgaria, Hungary and Romania, ICJ Reports (1950) p. 65 (s. 74).

60 Nuclear Tests, (Australia v. France, New Zealand v. France), ICJ Reports (1974), pp. 253 (s. 271, odst. 55), (s. 457 , odst. 58 ). 
Určující zásadou, která bezvýhradně ovládá jurisdikci Dvora ratione materiae, je princip konsensuální jurisdikce (popsán výše). Nedotknutelnost této zásady jednoznačně potvrzuje judikatura Dvora, resp. obou soudů. Dvưr je velmi obezřetný při výkladu věcného rozsahu jurisdikce, kterou na něj strany delegovaly. Striktně dbá, aby nepřekročil limity, v nichž na něj státy rozhodovací pravomoc přenesly. ${ }^{61}$

Lze ještě upřesnit, že Dvưr jasně řekl, že na konsensuálním principu nemění nic ani to, jedná-li se ve sporu o porušení norem ius cogens, resp. pravidel, která se uplatňují erga omnes. ${ }^{62}$

Podle čl. 36 Statutu MSD, který upravuje materiální jurisdikci, státy mohou udělit souhlas s jurisdikcí Dvora různými způsoby a v různém rozsahu. Poměrně široká škála těchto forem byla vedena snahou co nejvíce podpořit přijímání jurisdikce státy. Vstř́cnost se ze strany Dvora projevuje snížením formálních nároků na úkony, kterými je jurisdikce prrijímána. Dvůr dokonce připouští i způsob přijetí jurisdikce, který čl. 36 Statutu MSD vůbec neupravuje, tím, že aplikuje tzv. princip forum prorogatum.

Obecně lze konstatovat, že jednotlivé formy přijímání jurisdikce, a především pak přijímání obligatorní jurisdikce $\mathrm{v}$ širším smyslu, jakož i jejich uplatňování v praxi, představuji velmi složitou a technickou právní oblast s velkým množstvím kasuistiky (níže budou představeny jen stručně).

Dalším základním principem, který ovládá celou oblast materiální jurisdikce, je princip reciprocity. Výslovně je sice zmíněn jenom v čl. 36 odst. 2 Statutu, ale dopadá na všechny způsoby přijetí jurisdikce. Neomezuje se na rovinu vzájemnosti ratione personae, ale uplatňuje se také co do rozsahu ratione materiae. $\mathrm{V}$ př́ípadě smluv je to celkem samozřejmé, ale platí to i pro (jednostranné) prohlášení o prrijetí obligatorní jurisdikce.

\subsection{ZVLÁŠTNÍ DOHODA O ZALOŽENÍ PŘÍSLUŠNOSTI DVORA AD HOC}

Jednou z forem, kterými lze jurisdikci Dvora přijmout, je dohoda stran sporu o tom, že předloží svi̊j spor MSD. Za tím účelem uzavřou dohodu ad hoc o předložení sporu Dvoru, označovanou jako speciální či zvláštní dohoda (běžně označovaná jako compromis, resp. česky též „kompromis“). Tento způsob príijetí jurisdikce je upraven v čl. 40 odst. 1 Statutu. Ten předpokládá, že strany notifikují kompromis Dvoru společně, nicméně v praxi na této podmínce Dvưr netrvá. Rozhodujícím znakem tohoto způsobu založení jurisdikce Dvora je jeho povaha ad hoc, tedy že se vztahuje ke konkrétnímu, již nastalému sporu.

Vzhledem k tomu, že v takové situaci si obě strany přejí, aby jejich spor vyřešil Dvůr, prakticky nehrozí podávání předběžných námitek, a tudíž ani riziko, že spor skončí v předběžné fázi (ač to neplatí bezvýjimečně).

61 Viz např. Mavrommatis, Rights of Minorities in Upper Silesia, Interpretation of Peace Treaties, Anglo-Iranian Oil Case, Monetary Gold Removed from Rome, Aerial Incident of 27 July 1955, Nicaragua, Certain Phosphate Lands in Nauru, East Timor, Land and Maritime Boundary, Legality of Use of Force, Armed Activities, Certain Questions of Mutual Assistance in Criminal Matters.

62 East Timor (Portugal v. Australia), Judgment, I.C.J. Reports 1995, p. 90. 
Tento způsob přijetí jurisdikce se uplatňuje zejména ve vztahu k určitým typům sporů, jako jsou např́klad spory hraniční. I tento způsob založení jurisdikce má přirozeně své meze. Žádný „,velký“, politicky významný př́ípad se touto cestou před Dvůr nedostal. ${ }^{63}$ Praxe tím ukazuje, že by si mezinárodní soudnictví pouze s touto formou založení jurisdikce nevystačilo.

\subsection{PROHLÁŠENÍ O PŘIJETÍ OBLIGATORNÍ JURISDIKCE PODLE ČL. 36 ODST. 2 STATUTU MSD}

Prohlášení o přijetí obligatorní jurisdikce podle čl. 36 odst. 2 Statutu MSD $^{64}$ má určitá specifika a z nich vyplývající zvláštní význam. Zatímco ostatní formy přijetí jurisdikce Dvora se týkají př́islušnosti v konkrétní věci (zvláštní dohoda, forum prorogatum) nebo materiálně úzkého okruhu sporů (kompromisní doložky mezinárodních smluv), príjetím jurisdikce Dvora prohlášením podle čl. 36 odst. 2 Statutu MSD vzniká stav, který se relativně nejvíce (i když stále jen velmi, velmi vzdáleně) přibližuje modelu jurisdikce vnitrostátních soudů $\mathrm{v}$ tom směru, že se vztahuje na okruh př́padů, který zásadně není předem omezen početně ani věcně (platí to ovšem jen za předpokladu, že tento rozsah drasticky neomezí výhrady, a jen v relacích mezi státy, které príijaly týž závazek). Tato forma přijetí jurisdikce vlastně vyjadřuje značnou důvěru státu, který toto prohlášení činí, vi̊či MSD. Rosenne vidí tento způsob přijetí jurisdikce jako „nejpozoruhodnějš́ pokrok v technikách přijímání jurisdikce“" ${ }^{65} \mathrm{Na}$ druhou stranu i tento institut má své meze.

Neomezenou diskreci států, zda a v jakém rozsahu príimou jurisdikci Dvora prostřednictvím jednostranného prohlášení, a zároveň charakteristiku tohoto institutu Dvưr zdůraznil ve věci Military and Paramilitary Activities in and against Nicaragua. Jurisdiction of the Court, kde pravil: „Prohlášeni o príietí obligatorni jurisdikce Dvora jsou fakultativní, jednostranné závazky a státy mají absolutní svobodu je učinit, nebo neučinit. Když prohlášení činí, má stát stejně tak svobodu učinit jej bezpodmínečně a bez časového omezení, nebo jej omezit podmínkami a výhradami."“66

63 ZIMMERMAN - OELLERS-FRAHM - TOMUSCHAT - TAMS, The Statute of the International Court of Justice: A commentary, s. 662.

64 Pro větši přehlednost cituji čl. 36 odst. 2 a následující Statutu MSD (v českém znění, publikovaném pod č. 30/1947 Sb.):

„(2) Státy, které jsou stranami zúčastněnými na tomto statutu, mohou kdykoli prohlásiti, že uznávaji vůči kterémukoli jinému státu, který přijímá týž závazek, za závaznou ipso facto a bez zvláštního ujednání př̀slušnost Dvora ve všech právnich sporech, které se týkaji:

a) výkladu některé smlouvy;

b) kterékoli otázky mezinárodního práva

c) skutečnosti jakéhokoli faktu, který by, jestliže by byl prokázán zakládal porušení některého mezinárodního závazku;

d) povahy nebo rozsahu náhrady za porušeni mezinárodního závazku.

(3) Shora dotčené prohlášeni může býti učiněno nepodmíněně nebo s podmínkou vzájemnosti ze strany několika neb nékterých států nebo na určitou dobu.

(4) Toto prohlášeni se uloži u Generálního tajemnika Spojených národi̊, který odevzdá jeho opisy stranám zúčastnèným na statutu a tajemníku Dvora."

65 ROSENNE, The World Court: What it is and how it works.

66 Military and Paramilitary Activities in and against Nicaragua (Nicaragua v. United States of America), Jurisdiction and Admissibility, Judgment, I.C.J. Reports 1984, p. 392 (viz bod 59). 
Naděje zakladatelů systému ohledně opčních prohlášení nedošly v praxi naplnění. V současné době jsou platná prohlášení více než sedmdesáti států. Prohlášení jsou navíc omezena mnohdy rozsáhlými výhradami, které vylučují z príjetí spory různých kategorií.

Na dopad výhrad upozornil prof. C. H. M. Waldock, když uvedl, že ,př́istup státı̊ $k$ opčnímu prohlášení může zdegenerovat v čirý oportunismus, $k d y$ výhrady budou činěny, rušeny a měněny podle diktátu momentálních zájmů státư" ${ }^{67}$ Jako důkaz opodstatněnosti této obavy může posloužit např́íklad př́ípad Fisheries Jurisdiction (Spain v. Canada), Jurisdiction of the Court ze dne 14. prosince $1998 .{ }^{68} \mathrm{~V}$ tomto prípadě Kanada upravila své prohlášení v souvislosti s príjetím vnitrostátního zákona, který byl v rozporu s mezinárodním právem, tak, aby mezinárodní spory vzešlé z nové vnitrostátní úpravy byly z jurisdikce Dvora vyňaty. Tento jasně deklarovaný záměr vedl k tomu, že Dvưr ve sporu, který skutečně vznikl, nebyl př́slušný.

Právo činit výhrady z doslovného znění Statutu sice nevyplývá, nicméně bylo vždycky uznáváno a nikdy ani nebylo zpochybňováno. Soudce Kooijmans k tomu podotkl: „Je vskutku ironii, že Společnost národů ve své snaze povzbudit přijímání jurisdikce Dvora podpořila činění výhrad k tomuto přijetí (ačkoli čl. 36 odst. 3 Statutu stát, který prohlášení činí, $k$ prïijimáni formálně nezmocňuje), čimž oslabila systém, který zamýšlela posilit." 69

Z principu reciprocity prohlášení o přijetí obligatorní jurisdikce plyne, že věcný rozsah, $v$ němž strany přijaly jurisdikci Dvora, se $\mathrm{k}$ tomu, aby byla jurisdikce založena v konkrétním sporu, musí překrývat. Žalovaný tedy může vůči žalobci uplatňovat nejen svou vlastní výhradu, ale též výhradu, kterou ve svém prohlášení učinil žalobce.

Pokud jde o pravidla pro výklad opčních prohlášení, je důležité mít na paměti, že jednostranné prohlášení není smlouva. Dvưr shledal, že jeho výklad se řídí režimem odlišným od režimu výkladu mezinárodních smluv podle Vídeňské úmluvy o smluvním právu. Neuplatní se tak princip contra proferentem, ani princip efektivity a zejména se neuplatní zásada, že výhrady mají být vykládány restriktivně. Podstatné rovněž je, že Dvůr klade důraz na skutečnou vůli státu v době, kdy bylo prohlášení učiněno, a neomezuje se jen na výklad pouhého slovního textu prohlášení. ${ }^{70}$

\subsection{DOLOŽKA MEZINÁRODNÍ SMLOUVY O ZALOŽENÍ JURISDIKCE DVORA}

Ustanovení zakládající jurisdikci MSD obsahují jak smlouvy dvoustranné, tak i multilaterální. Tyto tzv. kompromisní či jurisdikční doložky stanoví, že spory, které vzniknou z aplikace či výkladu této smlouvy, mohou strany předložit Mezinárodnímu soudnímu dvoru.

$\mathrm{V}$ době Společnosti národů a $\mathrm{v}$ počátcích OSN bylo standardní praxí inkorporovat jurisdikční doložky do obecných multilaterálních smluv. Posléze jejich význam upadl

67 WALDOCK, C. H. M. Decline of the Optional Clause. The British Yearbook of International Law, 1955-56.

68 Fisheries Jurisdiction (Spain v. Canada), Jurisdiction of the Court, Judgment, ICJ Reports 1998, p. 432.

69 Separátní vótum soudce Kooijmanse, Fisheries Jurisdiction (Spain v. Canada), Jurisdiction of the Court, Judgment, ICJ Reports 1998, p. 489 (viz odst. 3).

70 Anglo-Iranian Oil Co. case (jurisdiction), Judgment of July 22nd, 1952, I.C J. Reports 1952, p. 9. 
v důsledku výhrad proti těmto doložkám (které systematicky uplatňovaly především státy socialistického bloku). V poslední době význam jurisdikčních doložek coby právního základu jurisdikce početně vzrůstá. Jak poznamenává Tomuschat, kompromisní doložky mohou být zdrojem překvapení, jako byl např́ílad pokus Srbska zahájit řízení proti členským státům NATO na základě kompromisní doložky v Úmluvě o genocidiu nebo pokus Gruzie zahájit řízení proti Rusku na základě Úmluvy o potlačení všech forem rasové diskriminace. ${ }^{71}$

$\mathrm{Z}$ povahy takto přijaté jurisdikce přirozeně plyne, že je často předmětem výkladu $v$ rámci předběžné fáze ř́ízení o námitce nepř́slušnosti.

\subsection{FORUM PROROGATUM}

Dalším způsobem přijetí jurisdikce pro konkrétní spor je tzv. forum prorogatum.

V podstatě zahrnuje případy, kdy žalovaná strana nepřijala k datu podání žaloby jurisdikci Dvora, ale učiní tak později, čímž se nedostatek jurisdikce k datu podání žaloby zhojí. Žalovaná strana může v těchto př́padech akceptovat jurisdikci Dvora jakýmkoli způsobem - výslovně nebo tacitně.

Tento způsob založení jurisdikce Statut MSD nezná. ${ }^{72}$ Pokud jde o systematické zařazení, forum prorogatum tak trochu ,visí “ mimo systém. Ačkoli někteří autoři jej přiřazují ke smluvnímu založení jurisdikce, ${ }^{73}$ dle mého soudu se jedná o způsob založení jurisdikce sui generis. (Na rozdíl od př́ípadů, kdy je Dvưr Soud příslušný na základě mezinárodní smlouvy nebo opčního prohlášení, představuje forum prorogatum přijetí jurisdikce $a d$ hoc - stejně jako zvláštní dohoda. Forum prorogatum se však od zvláštní dohody podstatně liší v tom, že sporné řízení je zahajováno jednostranným právním úkonem (žalobou) a procesní strany mají postavení žalobce a žalovaného.)

V praxi je spíše výjimečným jevem. Uplatnil se již před SDMS, poprvé ve věci $M a-$ vrommatis Jerusalem Concessions (1925). Před MSD se tento princip poprvé uplatnil hned v případě Corfu Channel, ${ }^{74}$ a to poněkud netypickým způsobem, kdy žalovala Velká Británie Albánii na základě doporučení Rady bezpečnosti, aby strany neprodleně předložily svůj spor MSD. Albánie sice předtím nepřijala jurisdikci Dvora, a dokonce nebyla ani stranou Statutu MSD a protestovala proti postupu Velké Británie, která měla za to, že doporučení Rady bezpečnosti zakládá jurisdikci Dvora, nicméně ve svém dopise, kde mj. uvedla, že její postup nesmí založit precedens do budoucna, projevila ochotu se řízení účastnit. To Dvůr vyhodnotil jako souhlas Albánie s jurisdikcí.

V nedávných dvou případech projevila vstř́icnost vůči žalobě Francie, a to ve věci Certain Criminal Proceedings in France (Republic of the Congo v. France) a ve věci Certain Questions of Mutual Assistance in Criminal Matters (Djibouti v. France).

71 ZIMMERMAN - OELLERS-FRAHM - TOMUSCHAT - TAMS, The Statute of the International Court of Justice: A commentary, s. 660.

$72 \mathrm{~S}$ termínem jako takovým nepracuje ani Jednací rád MSD, který ovšem tento postup implikuje (čl. 38 odst. 5).

73 ZIMMERMAN - OELLERS-FRAHM - TOMUSCHAT - TAMS, The Statute of the International Court of Justice: A commentary, s. 661.

74 Corfu Channel case, Judgment on Preliminary Objection, ICJ Reports 1948, p. 15. 


\section{VZTAH MSD A RADY BEZPEČNOSTI Z HLEDISKA JURISDIKCE DVORA}

Občas lze postřehnout určité dezinterpretace v tom smyslu, že by snad aktivita Rady bezpečnosti v určitém sporu vytvářela překážku pro výkon jurisdikce Dvora. Dvůr se však k otázce své jurisdikce ve vztahu k aktivitám Rady bezpečnosti několikrát jasně vyslovil. ${ }^{75}$

Ve věci United States Diplomatic and Consular Staff in Tehran (United States of America v. Iran) Dvưr uvedl, že ,zatímco čl. 12 Charty výslovně zakazuje Valnému shromáždění činit doporučení ve sporu nebo situaci, pokud ve vztahu k tomuto sporu nebo situaci vykonává své funkce Rada bezpečnosti, žádné ustanovení Charty ani Statutu nestanovi takové omezení pro výkon funkci Dvora. Di̊vody jsou zřejmé. Dvoru, hlavnímu soudnímu orgánu OSN, je určeno rozhodovat o jakékoli právní otázce (...).“

Ve věci Military and Paramilitary Activities in and against Nicaragua (Nicaragua v. United States of America) Dvưr upozornil na to, že podle čl. 24 Charty OSN má Rada bezpečnosti primární, nikoli však výlučnou odpovědnost za udržování mezinárodního míru a bezpečnosti. K tomu dodal, že „Radě jsou uloženy funkce bezpečnostního charakteru, zatímco Dvi̊r vykonává čistě judiciální funkce. Oba orgány tudiž mohou vykonávat své odlišné, ale komplementární funkce ve vztahu ke stejným př́padưm." Uvedenou tezi Dvůr potvrdil ve všech dalších prrípadech, kde se oba orgány zabývaly stejnou záležitostí. ${ }^{76,77}$

Poté, co bylo řízení před Dvorem platně zahájeno, přijetí rezolucí Rady bezpečnosti již nemůže mít vliv na jeho jurisdikci. Ve věci Questions of Interpretation and Application of the 1971 Montreal Convention arising from the Aerial Incident at Lockerbie), ${ }^{78}$ Dvůr konstatoval, že příslušné rezoluce Rady bezpečnosti byly přijaty až po podání žaloby a že pokud byla jeho jurisdikce dána k datu podání žaloby, bude ji mít i nadále a dotčené rezoluce na tom proto ani nemohou nic změnit.

Při rozboru vztahu Rady bezpečnosti a MSD je třeba vzít v úvahu i již zmíněný čl. 36 odst. 3 Charty OSN, který Radě bezpečnosti ukládá, aby při doporučování řešení sporů přihlížela $\mathrm{k}$ tomu, že spory právní povahy by strany měly zpravidla vznášet na MSD.

75 Tyto případy přehledně shrnuje Tomuschat v: ZIMMERMAN - OELLERS-FRAHM - TOMUSCHAT TAMS, The Statute of the International Court of Justice: A commentary, s. 645 a násl.

76 Application of the Convention on the Prevention and Punishment of the Crime of Genocide, Provisional Measures, Order of 8 April1993, I.C.J. Reports 1993, p. 3 (s. 19, odst. 33), kde Jugoslávie odkazovala na četné rezoluce Rady bezpečnosti, na to, že Rada přijala rozhodnutí podle čl. 25 Charty a výslovně upozornila na to, že jedná podle Kapitoly VII Charty; podle Jugoslávie by za takových okolností bylo uložení předběžných opatření předčasné a nepřiměřené; Dvůr se odvolal na své rozhodnutí ve věci Military and Paramilitary Activities in and against Nicaragua.

77 Armed Activities on the Territory of the Congo (Democratic Republic of the Congo v. Uganda), Provisional Measures, Order of 1 July 2000, I.C.J. Reports 2000, p. 111 (s. 126, odst. 36).

78 Questions of Interpretation and Application of the 1971 Montreal Convention arising from the Aerial Incident at Lockerbie (Libyan Arab Jamahiriya v. United States of America), Preliminary Objections, Judgment, I.C.J. Reports 1998, p. 115 (s. 129, odst. 37) a rovněž Questions of Interpretation and Application of the 1971 Montreal Convention arising from the Aerial Incident at Lockerbie (Libyan Arab Jamahiriya v. United Kingdom), Preliminary Objections, Judgment, I.C.J. Reports 1998, p. 9 (s. 23, odst. 38); Dvůr se tu zároveň odvolal na své rozsudky Nottebohm, Preliminary Objection, Judgment, I.C.J. Reports 1953, p. 122; Right of Passage over Indian Territory, Preliminary Objections, Judgment, I.C.J. Reports 1957, p. 142. 
Toto ustanovení se uplatnilo pouze poprvé, v případě Corfu Channel (United Kingdom of Great Britain and Northern Ireland v. Albania), kdy Rada bezpečnosti prímo doporučila stranám, aby předložily spor Dvoru. Podruhé se uplatnilo v „měkčíi formě, a to ve věci Aegean Sea Continental Shelf (Greece. v. Turkey). ${ }^{79}$

Je opět nutno zde zdůraznit, že ani doporučení Rady bezpečnosti předložit spor Dvoru nezakládá jurisdikci Dvora. I v těchto případech je nutné, aby obě strany jurisdikci ve vztahu k danému sporu přijaly. (Nejde o jednání Rady bezpečnosti podle Kapitoly VII Charty OSN.)

\section{1. ÚLOHA MSD A NĚKTERÉ OBECNÉ OTÁZKY}

\section{„PACIS TUTELA APUD IUDICEM“ \\ (nápis na Paláci míru, sídle Mezinárodního soudního dvora)}

I když bereme v úvahu specifika mezinárodního soudnictví, zásadu svrchované rovnosti a zásadu svobodné volby prostředků pokojného řešení sporů, nelze soudnictví upř́it určitou kvalitu, spojovanou se spravedlností. Mezinárodní soudní pravomoc, resp. soudnictví napomáhá nejen udržování míru, ale i rozvoji mezinárodního práva a rozumnému uspořádání vztahů v rámci mezinárodního společenství. To jsou ovšem hodnoty přesahující původní raison d'être Dvora, kterým bylo především poskytnout státům k dispozici efektivní prostředek pokojného urovnávání sporů.

Za sto let prodělalo mezinárodní právo značný vývoj. At’ už je to prosazení zákazu použití síly či obrovský nárůst reglementace mezinárodních vztahů. Vliv má i doktrína právního státu, která se uplatnila v řadě systémů vnitrostátního práva.

Prof. Bin Cheng během Konference Asociace pro mezinárodní právo odpověděl v roce 1964 v Tokiu kolegovi, jenž řekl, že existují prostředky urovnávání mezinárodních sporů stejně dobré jako soudnictví, následovně. ,Když (...) stát předem akceptuje povinnost jít před mezinárodní soud nebo arbitráž, povaha mezinárodního práva, které se v takovém připadě aplikuje, se změní. (...) Oproti mezinárodnímu právu auto-interpretačního typu má mnohem vyšši kvalitu. Obligatorní soudnictví není pouze další metodou řě̌ení mezinárodních spori̊. Pozvedá právo aplikovatelné mezi státy z auto-interpretačního na , souditelný 'stupeň. “"80

Proti těmto ideálům stojí politické zájmy států, které mezinárodní právo vytvářejí. Jakkoli během posledních sta let (zejména v posledních desetiletích) vznikla řada zejména partikulárních - systémů, které mají relativně efektivní vlastní judiciální, případně kvazijudiciální mechanismy, v oblasti „globální“ soudní pravomoci mezinárodní společenství nepostoupilo. Právní úprava sporné jurisdikce se nezměnila a lze říci, že se státy v oblasti přijímání jurisdikce MSD chovají podobně, jako v éře SDMS. Přijímání

79 SC Res 395 (1979), kde byla použita mnohem méně jednoznačná formulace, invites the Governments of Greece and Turkey (...) to take into account the contribution that appropriate judicial means, in particular the International Court of Justice, are qualified to make the settlement of any remaining legal differences".

80 Citováno podle separátního vóta, které připojil soudce Kooijmans k rozsudku ve věci Fisheries Jurisdiction (Spain v. Canada), Jurisdiction of the Court, Judgment, ICJ Reports 1998, p. 489. 
jurisdikce Dvora se nijak zvlášt' nerozšiřílo a není podmínkou vstupu do „dobré společnosti“. Ani stažením souhlasu s jurisdikcí bezprostředně před chystaným porušením mezinárodního práva se stát nijak zvlášst politicky ani morálně nezdiskredituje.

$\mathrm{S}$ tím souvisí otázka, jaké vlastně je místo mezinárodního soudnictví v katalogu prostředků pokojného řešení z hlediska aktuálního pozitivního práva.

Pokud jde o způsoby řešení mezinárodních sporů, zná současné mezinárodní právo jediný imperativ, a tím je pokojné urovnávání sporů ve smyslu Kapitoly VI Charty OSN. Ta zakotvuje princip svobodné volby prostředků. Platné právo neukládá státům, aby řešily své spory před soudem, a soudní řízení ani nijak nepreferuje. Jedinou výjimkou, resp. určitým atributem privilegovanosti soudního řešení, je čl. 36 odst. 3 Charty, jenž ukládá Radě bezpečnosti, aby při doporučování řešení sporů přihlížela $\mathrm{k}$ tomu, že „spory právní povahy by strany měly zpravidla vznášet na Mezinárodní soudni dvưr dle ustanovení jeho statutu“. Na toto „měkce“ formulované ustanovení se Dvůr ve své rozhodovací činnosti několikrát odvolal jako na podpůrný argument v souvislosti s vymezením svých kompetencí ve vztahu k Radě bezpečnosti. Když se však Dvůr vyjádřil př́mo k místu, které soudní řešení zaujímá mezi ostatními způsoby pokojného urovnávání sporů, a tedy i ke své roli v tomto ohledu, řekl: ,soudní řešení mezinárodních sporů, s ohledem na účel, k němuž byl Dvůr ustaven, je pouhou alternativou k prímému a prátelskému urovnáváni sporü mezi stranami; (...) tudiž je na Dvoru, aby usnadňoval, $v$ rozsahu, v jakém je to slučitelné se Statutem, toto prímé a prátelské urovnáni". To Dvůr uvedl ve svém rozsudku ve věci North Sea Continental Shelf. ${ }^{81}$ Přitom se odvolal na rozhodnutí SDMS ve věci Free Zones of Upper Savoy and the District of Gex. Platnost tohoto př́stupu pak potvrdil mj. v roce 2000 ve věci Aerial Incident of 10 August 1999 (Pakistan v. India), Jurisdiction of the Court (odst. 52). ${ }^{82}$

$\mathrm{S}$ ohledem na to, že soudní řešení de iure nemá přednost před ostatními formami mírového řešení sporů, znamená to, že jeho základním posláním je skutečně i dnes pouze řešení sporů (a tím i předcházení ohrožení mezinárodní bezpečnosti). Pozitivní vliv na rozvoj mezinárodního práva a další př́íznivé dopady s tím spojené jsou až sekundárním efektem jeho působení.

\section{ZÁVĚR}

Pro pochopení, jak sporná jurisdikce Dvora funguje, je třeba vnímat kontext, ve kterém vzniká a realizuje se, a který má různé roviny.

První rovinou je rámec historický. Oblast sporné jurisdikce se vyznačuje výraznou kontinuitou od vzniku SDMS až do dnešních dnů, a to jak v rovině právní úpravy, tak i praxe. Fenomén sporné jurisdikce se tak ukazuje jako „př́iběh“, jenž má své kapitoly, peripetie, vývoj i zlom (v podobě zániku jednoho a vzniku nového soudu), ale který pokračuje již téměř sto let, bez ohledu na změny, jimiž za tuto dobu mezinárodní společenství prošlo. To, že se v dnešní době uplatňuje sto let starý systém, může být interpre-

81 North Sea Continental Shelf, Judgment, I.C.J. Reports 1969, p. 3.

82 Aerial Incident of 10 August 1999 (Pakistan v. India), Jurisdiction of the Court, Judgment, ICJ Reports 2000, p. 12. 
továno bud' jako př́íznak jeho efektivního nastavení, nebo jako projev jeho zastaralosti a rigidity. V každém př́padě je však nepochybné, že současný mechanismus jurisdikce MSD prokázal a prokazuje obdivuhodnou životaschopnost.

Dalším rámcovým aspektem je povaha právní úpravy sporné jurisdikce. Základem jsou př́íslušná ustanovení Charty OSN a Statutu MSD. Psaná pravidla jsou však velmi stručná a neřeší všechny situace, $k$ nimž při jejich aplikaci dochází. Dvưr je proto musí dotvářet rozhodovací praxí. Mnohá z těchto pravidel založených judikaturou jsou natolik zásadní povahy, že bez jejich znalosti nelze způsob, jímž se sporná jurisdikce ve skutečnosti řídí, poznat. Jinými slovy, pouze z psaného práva jej nevyčteme. Význam judikatury v oblasti sporné jurisdikce je opravdu mimořádný.

Aspektem, který bývá v nauce poněkud opomíjen, je rovina procesní. Ta pomáhá pochopit logiku rrízení, v němž Dvůr o své jurisdikci rozhoduje (zpravidla řízení o předběžné námitce nepř́slušnosti Dvora) a usnadňuje práci s judikaturou. Nejvýznamnější dopad má to procesní pravidlo, podle kterého Dvưr o své jurisdikci rozhoduje rozsudkem (jenž je závazný stejně jako rozsudek ve věci samé).

Další oblastí relevantní pro pochopení problematiky sporné jurisdikce jsou nástroje, jimiž Dvůr svou jurisdikci zkoumá, a podmínky, za kterých tak činí.

Klíčové je ustanovení čl. 36 odst. 6 Statutu MSD, které zakotvuje princip compétence de la compétence. Toto ustanovení představuje nejvýznamnější mantinel zásady konsensuální jurisdikce. Je doplněno pravidlem, které vytvořila rozhodovací praxe a které stanoví, že okamžikem rozhodným pro určení existence a rozsahu jurisdikce Dvora je datum podání žaloby. Přesněji řečeno: jurisdikce jednou založená (stačí v den podání žaloby, ale může se tak stát i později) trvá až do rozhodnutí ve věci samé.

Mezi instituty specifického posuzování jurisdikce patří posuzování jurisdikce, které Dvůr provádí v príípadech, kdy se žalovaná strana neúčastní řízení, a rovněž posouzení jurisdikce Dvorem prima facie při ukládání předběžných opatření ve fázi ř́zení, kdy o jurisdikci ještě není rozhodnuto.

Pokud jde o spornou jurisdikci Dvora ratione personae, platí absolutní monopol států pro př́stup do sporného řízení. Ve srovnání s materiální jurisdikcí je personální jurisdikce méně komplikovaná a nebývá předmětem sporů často. $V$ př́padě, že se tak stane, může však mít takové rozhodnutí zásadní důsledky, nebot' v krajním př́ípadě může vést až $\mathrm{k}$ denegatio iustitiae. Byly to právě př́pady spojené s aplikací čl. 35 Statutu, kde se Dvůr dopustil zřejmě největšího dosavadního porušení integrity své judikatury.

Jurisdikce ratione materiae je plně ovládána konsensuálním principem. Dvůr může rozhodovat výhradně ve sporech, pro které strany sporu přijaly jeho jurisdikci. Nejméně komplikovaným způsobem je uzavření zvláštní dohody, kterou strany sporu přijímají jurisdikci Dvora pro konkrétní, již existující spor. Způsoby, jimiž státy přijímají jurisdikci Dvora předem (platí to i o jurisdikčních doložkách mezinárodních smluv), mají zvláštní význam. Při aplikaci těchto titulů vyniká mimořádný dopad principu compétence de la compétence, který limituje absolutní vládu států nad jurisdikcí Dvora.

Jak tedy může v horizontálním systému současného mezinárodního práva fungovat nad - resp. mezi - suverénními státy mezinárodní soud? Děje se tak za cenu určitých kompromisů a logických ústupků, které lze chápat jako inherentní problémy systému. Neuralgickým bodem je hranice mezi konsensuálním principem a sférou, kde se „pá- 
nem jurisdikce“ stává Dvůr. Nevyhnutelně nastávají situace, kdy se výkon pravomoci (v podobě samotného rozhodnutí o ní) na základě předem přijaté jurisdikce poté, co je řízení zahájeno, dostane do střetu s vưlí žalovaného státu. Udržet se na tenkém ostří hranice mezi zásadou konsensuální jurisdikce a principem compétence de la compétence je dle mého soudu největší výzvou, které musí Dvůr čelit. Ne vždy se to daří. Je však nutno rozlišovat, kdy měl na výběr a kdy uvízl v limitech systému, z nichž se nemůže vymanit.

MSD v rozsudku ve věci Application of the Convention on the Prevention and Punishment of the Crime of Genocide (Croatia v. Serbia) zdůraznil (či spíše „pochválil“) flexibilitu a realismus, které při uplatňování své jurisdikce v minulosti projevil. Ponechme stranou, že „flexibilita“ vedla právě zde k jednomu z nejméně přesvědčivých rozhodnutí, které kdy Dvůr o své jurisdikci vydal. Klíč k optimálnímu přístupu k jurisdikci MSD však spočívá ve druhém uvedeném prvku. Aby mezistátní soudnictví v dnešní podobě vůbec mohlo účelně fungovat, je nutný realismus jak na straně samotného soudu, tak i na straně subjektů práva (obecně) a př́padně stran sporu. To znamená, že je nezbytné mít stále na paměti reálné i právní možnosti a meze stávajícího systému soudní pravomoci a „nepodsouvat“ Dvoru úkoly, k nimž nedostal od států mandát. A k tomu, aby mohlo být mezinárodní soudnictví rozumně hodnoceno, je nutný realismus na straně odborné veřejnosti, včetně nauky. $\mathrm{K}$ tomu se tento článek snaží svým malým dílem přispět.

Mgr. Soňa Šindelková

Ministerstvo zahraničních věcí ČR

sona.sindelkova@seznam.cz 